\title{
Quaternary Evolution of the Lower Calore and Middle Volturno Valleys (Southern Italy)
}

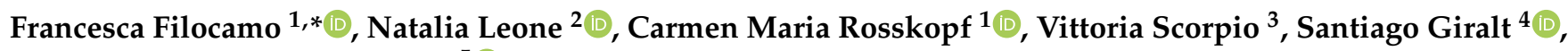 \\ and Pietro Patrizio Ciro Aucelli ${ }^{5}$ (i)
}

1 Department of Biosciences and Territory, University of Molise, Contrada Fonte Lappone, 86090 Pesche, Italy; rosskopf@unimol.it

2 Institute of Water Research-IRSA, Italian National Research Council, Viale F. De Blasio, 70132 Bari, Italy; natalia.leone@ba.irsa.cnr.it

3 Institute for Earth Observation, Eurac Research, Viale Druso 1, 39100 Bozen/Bolzano, Italy; vittoria.scorpio@eurac.edu

4 Geosciences Barcelona (Geo3BCN-CSIC), Lluís Solé Sabarís s/n, E-08028 Barcelona, Spain; sgiralt@geo3bcn.csic.es

5 Department of Science and Technology, University of Naples Parthenope, Centro Direzionale Isola C4, 80143 Napoli, Italy; pietro.aucelli@uniparthenope.it

* Correspondence: francesca.filocamo@gmail.com; Tel.: +39-0874-404168

check for updates

Citation: Filocamo, F.; Leone, N.; Rosskopf, C.M.; Scorpio, V.; Giralt, S.; Aucelli, P.P.C. Quaternary Evolution of the Lower Calore and Middle Volturno Valleys (Southern Italy). Water 2021, 13, 741. https:// doi.org/10.3390/w13050741

Academic Editor: Salvatore Ivo Giano

Received: 14 January 2021

Accepted: 2 March 2021

Published: 9 March 2021

Publisher's Note: MDPI stays neutral with regard to jurisdictional claims in published maps and institutional affiliations.

Copyright: (c) 2021 by the authors. Licensee MDPI, Basel, Switzerland. This article is an open access article distributed under the terms and conditions of the Creative Commons Attribution (CC BY) license (https:// creativecommons.org/licenses/by/ $4.0 /)$.

\begin{abstract}
The lower Calore and middle Volturno valleys preserve stratigraphical and morphological evidence and tephrostratigraphic markers particularly suitable for reconstructing the long-term geomorphological evolution of the central-southern Apennines. Aim of our study is to identify the main steps of the Quaternary landscape evolution of these valley systems and to improve knowledge about the relationships between fluvial processes and tectonics, volcanic activity, climatic and human influences. To this purpose, we carried out an integrated geomorphological and chronostratigraphical analysis of identified fluvial landforms and related deposits, integrated by ${ }^{230} \mathrm{Th} /{ }^{234} \mathrm{U}$ datings on travertines from the Telese Plain area. The study highlighted in particular: (1) fluvial sedimentation started in the Middle Pleistocene ( $650 \mathrm{ka}$ ) within valleys that originated in the lower Pleistocene under the control of high-angle faults; (2) extensional tectonics acted during the Middle and Upper Pleistocene, driving the formation of the oldest fluvial terraces and alluvial fans, and persisted beyond the emplacement of the Campanian Ignimbrite pyroclastic deposits ( 39 ka); and (3) from the late Upper Pleistocene onwards ( $<15 \mathrm{ka}$ ), the role of tectonics appears negligible, while climatic changes played a key role in the formation of three orders of valley floor terraces and the youngest alluvial fans.
\end{abstract}

Keywords: fluvial landforms; long-term geomorphological evolution; climate influence; tectonics; tephrostratigraphic marker; ${ }^{230} \mathrm{Th} /{ }^{234} \mathrm{U}$ dating; central-southern Apennines

\section{Introduction}

Physical landscapes and related landforms result from complex sequences and overlaps of geological and geomorphological processes that have contributed to its longterm shaping, therefore providing valuable information on past morphodynamics and geological events.

Considering in particular the context of a young and active mountain chain, such as the Apennines [1,2], long-term landscape evolution appears complex and diverse in space, mainly responding to tectonic events that have implicated diverse regimes and spatiotemporal scales for different chain sectors (e.g., [2,3]), and environmental changes due to volcanic events and/or climate oscillations and related sea level changes (e.g., [4,5] and references therein).

Analyzing such a long-term landscape can provide valid data about the Quaternary geomorphological evolution of a certain area and the roles played by tectonics and cli- 
mate changes (e.g., [6,7] and references therein). This is particularly true for terraced fluvial landscapes that can provide broad evidence about the relations of surface processes, tectonics, and climate influences [8-11]. Fluvial responses to phases of regional uplift (especially valley downcutting and widening) (e.g., [10]) and to climate fluctuations (especially warm-cold and cold-warm transitions) resulting in alternated phases of valley filling and incision $[5,12,13]$ are scientific issues of particular interest and high complexity (e.g., [14] and references therein).

Starting from these considerations, to improve our knowledge on the Quaternary evolution of the central-southern Apennines, we searched for a study area that could offer the following advantages: (i) being located in a sector of the Apennine chain that is part of a wider areal context for which essential data about geological history and tectonics are already available; (ii) being characterized by a rich, diversified fluvial landscape; (iii) being characterized by stratigraphical and geomorphological evidence providing morphochronological constraints suitable for landscape reconstruction. Once examined several regional contexts and relative data available, we focused our attention on the Volturno River system (Figure 1) that occupies a central position in the central-southern Apennines.

As highlighted by several studies, the Volturno valley preserves rich evidence about the morpho-evolutive events that have affected this sector of the Apennine chain during the Quaternary $[10,15,16]$. It represents a key area that hosts stratigraphical and morphological evidence along with several tephrostratigraphic markers suitable for investigating the long-term evolution of this active chain sector.

The upper Volturno River valley has been subject of various studies [15,17-23] that have provided a basic framework of its tectonic and sedimentary Quaternary evolution. Studies on the middle Volturno River valley mainly focused on the southern Matese mountain front and the adjoining Alife basin [16,24-28] (Figure 1b) and different reconstructions of the Quaternary tectonic framework are proposed [16,26], but no specific studies on fluvial terraces have been performed. Numerous studies concern especially the lower Calore River valley [15,29-34], the main left tributary of Volturno River, mainly aimed at the reconstruction of the morphotectonic framework and the identification of seismogenic faults. Different models for the morphotectonic and paleoenvironmental evolution have been proposed highlighting a number of open questions regarding mostly the origin and ages of the fluvial terraces that characterize this valley. However, except for the paper of Massa and Zuppetta [35], which focuses on the recent tectonic activity in the confluence area of Calore and Volturno rivers, studies about the evolution of the Calore and Volturno rivers valleys and related chronological aspects are completely lacking. Especially the relations between morphogenetic events, climate and tectonic drivers and the largest Quaternary volcanic explosive event in the Mediterranean region [36] that has given origin to the Campanian Ignimbrite (CI) pyroclastic flow deposits (39 ka [37]), have not been fully addressed and clarified.

Based on already acquired data and knowledge gaps, briefly outlined above, we selected the middle Volturno River valley including the lower Calore valley (Figure 1a) as our study area.

Given the purpose to reconstruct the Quaternary evolution of the study area, major specific goals of this study are (i) to reconstruct and characterize in detail the stratigraphical sequences of fluvial terraces and alluvial fans; (ii) to add morpho-chronological constraints suitable for framing the geomorphologic evolution of the study area; and (iii) to better understand the possible roles of tectonics, climate, and volcanic events in the development of the fluvial landscape. 

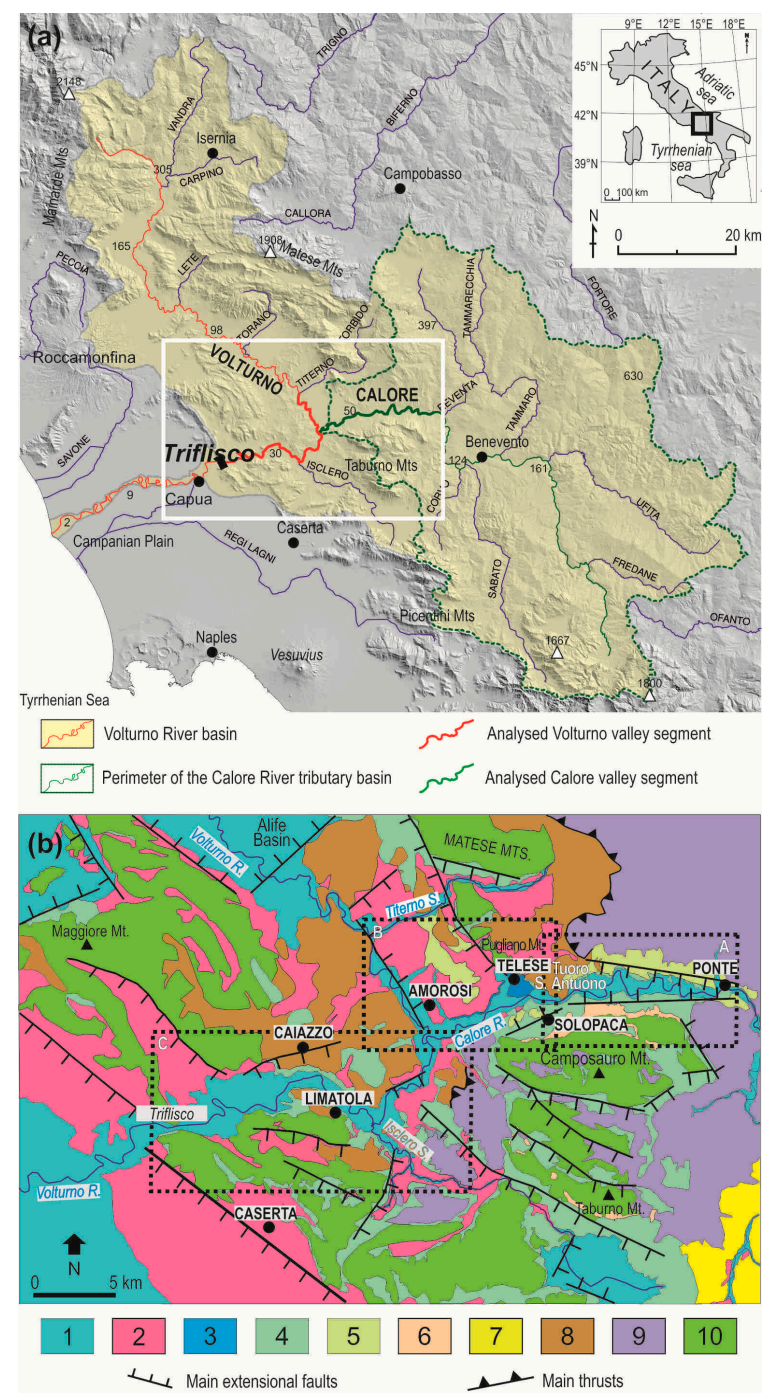

Figure 1. (a) The Volturno River basin and the analyzed segments of the Volturno and Calore valleys; (b) geological sketch map of the sector of the southern Apennine chain including the middle Volturno and lower Calore valleys. For location and limits, see the white box in (a). In dashed black frames the three study sectors A, B, and C. Legend: (1) Alluvial and lacustrine deposits (Upper PleistoceneRecent); (2) Volcanic deposits (Upper Pleistocene-Holocene); (3) Travertines (Upper PleistoceneHolocene?); (4) Eluvial-colluvial, slope, and alluvial fan deposits (Middle Pleistocene-Holocene); (5) Alluvial deposits (Middle-Upper Pleistocene); (6) Slope breccias of Laiano Synthem (Lower Pleistocene); (7) Sands, clays and conglomerates of Ariano Unit (Pliocene); (8) Siliciclastic deposits of Molise and Caiazzo Flysch (Upper Miocene); (9) Varicoloured clays, limestones, marls, and arenites of Sannio Units (Upper Cretaceous-Miocene); (10) Limestones and dolostones of Carbonate Platform Units (Trias-Miocene).

\section{Study Area}

The Volturno River, with a length of $\sim 175 \mathrm{~km}$ and a catchment area of $5500 \mathrm{~km}^{2}$, is the largest river in southern Italy. The Calore River, with a length of $208 \mathrm{~km}$ and a catchment area of $3058 \mathrm{~km}^{2}$, is its main left tributary (Figure 1a).

The upper and middle stretches of Volturno River flow through a wide valley that crosses the axial zone of the central-southern Apennine chain. The lower segment of the Volturno River crosses the northern sector of the Campania coastal alluvial plain which is part of the broad peri-Tyrrhenian Piana Campania Graben [38,39]. The sector of the southern Apennine chain that includes the middle Volturno River valley is part of a Neogene fold and thrust system generated by complex tectonic deformations started 
during the Miocene [40,41]. The tectonic units consist of carbonate platform and basinal Meso-Cenozoic sedimentary successions [42,43] (Figure 1b), which were progressively incorporated in the Apennine accretionary wedge [44]. This sector of the Apennine chain emerged since the Pliocene [45]. Starting from the Lower Pleistocene, it was affected by NW-SE extensional tectonics that generated high-angle fault systems mainly composed of NW-SE trending strike-slip and NE-SW trending normal faults, responsible for the onset of Quaternary fluvial and slope sedimentation [46]. In the Middle Pleistocene, a change in the direction of extension, from NW-SE to NE-SW, caused the reactivation of previous structures, especially those oriented in the NW-SE direction [32,47-49].

The pre-Quaternary bedrock mainly consists of Mesozoic-Cenozoic limestones and dolostones belonging to carbonate platform units, which are overlain by the terrigenous successions of the Upper Miocene Molise and Caiazzo Flysch [50] (Figure 1b). The latter are covered by basinal successions of the Sannio units that crop out in the eastern sector of the study area.

Quaternary deposits are widespread in both the middle Volturno and the lower Calore valleys (Figure 1b). They consist of fluvial, alluvial fan, eluvial-colluvial, slope, travertine, and volcanic deposits. The latter are prevailingly represented by the CI pyroclastic flow deposits (for details, see Section 2.1).

For this study, the following three valley sectors A, B, and C (Figure 1b), were considered.

Sector A coincides with the portion of the lower Calore River valley that extends between the villages of Ponte and Tuoro S. Antuono (Figure 1b). In this sector, the Calore River has a meandering planform morphology and crosses a structurally controlled, E$\mathrm{W}$ elongated valley depression, limited to the north by the gentle marginal slopes of Matese Massif, mainly made of terrigenous and basinal successions of the Molise Flysch and Sannio Unit, and to the south by the steep Camposauro carbonate mountain front (Figure 1b).

Sector B includes the portion of the lower Calore River valley located between Tuoro S. Antuono and the confluence with the Volturno River, and the stretch of the middle Volturno River valley located between the confluences of the Titerno Stream and the Calore River (Figure 1b). In this sector, the Calore River maintains a meandering planform morphology. The Volturno River has a length of $\sim 10 \mathrm{~km}$ and a sinuous to meandering channel [51] and crosses a NW-SE elongated structurally controlled valley depression, mainly underlain by Miocene flysch deposits.

Finally, sector $C$ consists in the stretch of the middle Volturno valley that extends between the Calore confluence and the Triflisco dam (Figure 1b). Upstream the confluence of Isclero Stream, the Volturno has a length of $9 \mathrm{~km}$, a sinuous morphology, and follows a prevailing NE-SW direction, crossing a valley mainly underlain by Miocene Flysch deposits. Downstream the Isclero confluence, the Volturno channel has a length of $\sim 17 \mathrm{~km}$ and a prevailing meandering morphology; it maintains a prevailing NE-SW direction and is mainly underlain by Mesozoic carbonate rocks.

\subsection{Literature Overview of Quaternary Deposits}

To summarize pre-existing data and highlight related knowledge gaps, we performed a detailed literature review of Quaternary deposits.

The oldest outcropping Quaternary deposits are preserved in the lower Calore valley (sectors A and B in Figure 1b). These are mainly terraced alluvial deposits, widespread on the northern valley slope, and slope and alluvial fan deposits prevailing on the southern slope. Among the latter, the oldest deposits are the tectonized and well-cemented Lower Pleistocene Laiano Synthem slope breccias [45], which are widespread along the northern slope of Camposauro Mt (Figure 1b). Alluvial fan deposits were found widely in the Calore valley and several generations have been distinguished by different authors [15,31-35], but without agreeing on the number of generations and related ages. In particular, Massa et al. [31], Di Bucci et al. [32,33] and Massa and Zuppetta [35] have distinguished two generations referred, respectively, to the Upper Pleistocene and the Early Holocene, 
while Magliulo et al. [34] highlighted the presence of three generations but without providing chronological constraints. Recently Amato et al. [15] highlighted the presence of four generations of superimposed or entrenched alluvial fan systems grown above the Laiano Synthem slope breccias. The first generation was chronologically constrained to the late Middle Pleistocene-early Upper Pleistocene, based on $158 \pm 6-113 \pm 7 \mathrm{ka}{ }^{40} \mathrm{Ar} /{ }^{39} \mathrm{Ar}$ dated tephra layers interbedded in its upper part. The second generation was referred to the Upper Pleistocene thanks to the presence of a $48 \pm 7 \mathrm{ka}{ }^{40} \mathrm{Ar} /{ }^{39} \mathrm{Ar}$ dated tephra layer and a CI tephra layer ( $\sim 39 \mathrm{ka})$ interbedded in the upper part. The third generation was constrained to the end of the Upper Pleistocene-Holocene based on the presence of a Neapolitan Yellow Tuff tephra layer (NYT hereinafter; 15 ka [52]) in its upper part. Finally, the fourth generation was referred to the Holocene.

Ancient terraced gravelly-sandy alluvial deposits crop out extensively along the right Calore valley flank between the villages of Ponte and Solopaca [29-34] (sector A, Figure 1b) between $\sim 65 \mathrm{~m}$ and $\sim 220 \mathrm{~m}$ a.s.l. According to Magliulo [30] and Magliulo et al. [34], these deposits are the product of a single, prolonged phase of valley aggradation during the Middle Pleistocene $\left(560 \pm 2 \mathrm{ka}{ }^{39} \mathrm{Ar} /{ }^{40} \mathrm{Ar}\right.$ age of an interlayered ignimbrite deposit [30]) followed by several phases of terrace formation due to valley incision during the Middle and Upper Pleistocene. Conversely, Massa et al. [31] and Di Bucci et al. [32,33] consider these terrace orders the result of separated depositional/erosional events. According to Di Bucci et al. [32], the sedimentation of these ancient alluvial deposits can be chronologically constrained between the Middle and the Upper Pleistocene, thanks to the presence of volcanic deposits (a $674 \pm 10 \mathrm{ka}{ }^{40} \mathrm{Ar} /{ }^{39} \mathrm{Ar}$ dated pyroclastic layer, a tephra layer in the upper part of the succession with an ${ }^{40} \mathrm{Ar} /{ }^{39} \mathrm{Ar}$ age of $97 \pm 25 \mathrm{ka}$, CI deposits covering the succession). A Middle Pleistocene age for the oldest alluvial terraced deposits is indicated also by Amato et al. [15] based on the $648 \pm 6 \mathrm{ka}{ }^{40} \mathrm{Ar} /{ }^{39} \mathrm{Ar}$ age of an interbedded tephra layer. In sector $\mathrm{B}$, ancient terraced alluvial deposits are represented by smaller outcrops in the piedmont area of the Camposauro Mt. (Solopaca area, Figure 1b), referred to the Middle-Upper Pleistocene S. Leonardo sub-Synthem [45], and by larger surfaces located on the right flank of the Calore valley (Telese Plain area, between Telese and Amorosi, Figure 1 b) referred to the Upper Pleistocene $[33,53]$.

In the Telese and Amorosi areas (sector B, Figure 1b), the ancient alluvial deposits are covered by travertines related to the springs of Telese and Grassano, located along the southern slope of Pugliano Mt. [54,55] and fed by the Matese Mts. Aquifer. The Amorosi travertines are mainly characterized by phytohermal facies and covered by CI pyroclastic flow deposits forming a wide terraced surface, the Amorosi terrace. These travertines are referred to the Amorosi sub-Synthem [45] and dated to the Upper Pleistocene [45,53,56,57]. The Telese travertines form a large, terraced surface (hereinafter Telese Terrace) on which the town of Telese is placed. They mainly consist of lacustrine facies passing laterally and upwards to swamp facies [56]. Near the Telese springs, travertines are still forming today and Aiello et al. [56] and Del Prete et al. [57] suggest the possibility that the formation of the Telese Terrace occurred even after the CI deposition.

CI pyroclastic flow deposits often form terraced surfaces and are widespread in the Calore and Volturno confluence area and in the middle Volturno River valley (sectors B and C) where they unconformably overlie the oldest Quaternary deposits or the preQuaternary bedrock. Reworked CI tephra layers embedded in alluvial deposits prevail, instead, in sector A [15]. Alluvial valley floor deposits in the lower Calore River valley (sectors A and B in Figure 1b) are mainly represented by silty sands and gravels. Two terrace orders are distinguished by [30-34]: Massa et al. [31] and Di Bucci et al. [32,33] consider them as depositional in origin, referring the older one to the late Upper Pleistocene and the younger one (containing reworked terracotta fragments with maximum ages $<7 \mathrm{ka}$ ) to the Holocene, while Magliulo [30] and Magliulo et al. [34] interpret the upper terrace as erosional in origin and the lower one as depositional, referring them respectively to the late Upper Pleistocene-Early Holocene and the Middle-Late Holocene. In sector A, the two valley floor terraces complete the flights of fluvial terraces that characterize the right flank 
of the lower Calore River valley, made of a total of five terrace orders referred to the Middle Pleistocene-Holocene time interval [30-34].

Alluvial valley floor deposits present downstream the Calore confluence (sector $\mathrm{C}$ in Figure 1b) are referred to the Upper Pleistocene-Holocene Limatola Synthem [45]. They consist of sandy silts and sands of prevailing pyroclastic nature, with carbonate or polygenic gravelly lenses. Near the Calore confluence, Massa and Zuppetta [35] distinguished within these deposits two orders of fluvial terraces that they referred, respectively, to the Upper Pleistocene and the Holocene.

However, the examined literature highlights several divergences between the various authors as for the correlation of terrace remnants and their inclusion in one order or another. Such differences in grouping terrace remnants, regarding above all the oldest ones, are probably mainly related to their high fragmentation due to valley downcutting by the right tributaries of Calore River, and to tectonics. In particular, as reported by Di Bucci et al. [32,33] and Magliulo et al. [34], high-angle faults affect the oldest terraces orders.

\section{Materials and Methods}

The general picture of the data that emerged from the critical revision of literature represents an essential, even if preliminary result of the present study. On its basis, methods and related research activities were defined to front existing knowledge gaps and improve the overall knowledge framework.

\subsection{Geomorphological Analysis}

The geomorphological analysis mainly focused on the identification of Quaternary fluvial landforms.

We performed a multi-temporal analysis based on large-scale topographic maps (Carta Tecnica Regionale of Campania Region, 1992, in scale 1:5000), aerial photos of 1954 and orthophotos of 1998, 2004, and 2011, and a high resolution DTM (5 m per pixel). To map the valley floor features, we also used I.G.M.I. (Istituto Geografico Militare Italiano, Florence, Italy) topographic maps in scale 1:50,000 edited in the years 1834 (Calore valley, sectors A and B), 1860 (Volturno valley between the Titerno and Calore confluences, sector B; Calore valley in sectors A and B), 1875-1876 (Calore valley in sectors A and B, and Volturno valley between the Calore confluence and the Triflisco dam, sector C). All historical maps were scanned with a resolution of $300 \mathrm{dpi}$ and georeferenced in the UTMWGS84 coordinate system using the Arc-GIS 10.7 software. The multitemporal analysis of topographic maps allowed dating the most recent valley floor terraces. According to this approach, the terraces that formed later than the year of edition of one of the historical maps (1834-1876), have been referred, for uniformity, altogether to the post-1870s.

Using the ArcGIS 10.7 software, we produced a geomorphological sketch focused on fluvial landforms of the study area. All mapped elements were checked with the help of field surveys and stratigraphic data derived from boreholes. To better correlate the mapped fluvial terrace remnants (especially the recent valley floor terraces), longitudinal terrace and thalweg profiles of Volturno and Calore rivers were reconstructed and plotted on a Cartesian plane reporting the distances on the x-axes and the elevation above sea level along the y-axes. For each terrace, the longitudinal average elevations found along the inner edges were plotted on a plane.

\subsection{Stratigraphical Analysis}

The stratigraphical analysis mainly focused on the definition of the morpho-stratigraphical framework of the study area and the characterization of both the valley fillings and the stratigraphical features of the terraced fluvial landforms. This analysis was essentially based on field surveys and the examination of 82 borehole logs provided by public institutions and private companies. Stratigraphical data extracted from boreholes were analyzed and compared with those derived from outcropping successions. Field surveys also al- 
lowed identifying and characterizing different tectonic features that affect the investigated Quaternary successions.

\section{3. ${ }^{230} \mathrm{Th} /{ }^{234} U$ Datings on Travertines}

Uranium-series disintegration method $\left({ }^{230} \mathrm{Th} /{ }^{234} \mathrm{U}\right)$ was performed on five travertine samples to obtain a chronological framework of the studied deposits. These samples were collected (for precise location see Section 4.2.2. and related figure) in the areas of Telese and Amorosi (sector B, Figure 1b), respectively, along the banks of Telese Lake in the uppermost part of the succession ( $\operatorname{Tr} 1$ at $47 \mathrm{~m}$ a.s.l. and $\operatorname{Tr} 2$ at $51 \mathrm{~m}$ a.s.l.) and along the scarps of the Amorosi terrace in the middle part of succession ( $\operatorname{Tr} 3$, at $54 \mathrm{~m}$ a.s.l., $\operatorname{Tr} 4$ at $53.5 \mathrm{~m}$ a.s.l. and $\operatorname{Tr} 5$ at $53 \mathrm{~m}$ a.s.l.).

The radiometric ages were obtained through alpha-spectrometry using an ORTEC OCTETE PLUS spectrometer equipped with eight BR-024-450-100 detectors from the Geosciences Barcelona (Geo3BCN-CSIC, Barcelona, Spain). The chemical separation of the radioisotopes and purification from travertine samples $(\sim 20 \mathrm{~g})$ was conducted following the procedure described by Bischoff et al. [58] and isotope electrodeposition was done according to the method of Talvitie [59], modified by Hallstadius [60]. Absolute ages were obtained employing the software designed by Rosenbauer [61].

\section{Results}

\section{1. ${ }^{230} \mathrm{Th} /{ }^{234} U$ Datings}

Only the Tr2 sample contained $>15 \%$ wt of insoluble residue that impeded obtaining a reliable age. The other four samples yielded the radiometric ages reported in Table 1. Among these four travertine samples, $\operatorname{Tr} 1, \operatorname{Tr} 4$, and $\operatorname{Tr} 5$ samples contain a significant amount of siliciclastic material that may contribute with terrigenous ${ }^{232} \mathrm{Th}$ adsorbed in the octahedric layers of detrital clays. However, the relation between the ${ }^{230} \mathrm{Th}$ from the disintegration of the uranium and the detrital ${ }^{232} \mathrm{Th}$ from Amorosi travertines is higher than two, which means that contamination can be considered negligible. That is not the case of the Tr1 sample. Moreover, the ratio ${ }^{230} \mathrm{Th} /{ }^{234} \mathrm{U}$ of Amorosi samples is $0.55 \pm 0.02$, indicating that the radiometric clock has remained closed since the formation of these travertines whereas this ratio is $1.30 \pm 0.05$ for the Tr1 sample, suggesting that it might have suffered post-depositional alterations. Therefore, from an analytical point of view, the obtained radiometric ages for the Amorosi samples can be considered valid because the detrital contamination is relatively small and the radiometric clock of the U-Th system has been closed since the travertine formation, while the radiometric age obtained for $\operatorname{Tr} 1$ must be considered with caution.

Table 1. U-series radiometric data and derived dates for the Telese and Amorosi travertine samples.

\begin{tabular}{cccccccr}
\hline Sample & Ref-Lab & ${ }^{238} \mathbf{U}(\mathbf{p p m})$ & ${ }^{232} \mathbf{T h}(\mathbf{p p m})$ & ${ }^{234} \mathbf{U} /{ }^{238} \mathbf{U}$ & ${ }^{{ }^{230} \mathbf{T h} /{ }^{232} \mathbf{T h}}$ & ${ }^{230} \mathbf{T h} /{ }^{234} \mathbf{U}$ & $\begin{array}{r}\text { Nominal Date } \\
(\mathbf{Y e a r s} \mathbf{B P})\end{array}$ \\
\hline $\operatorname{Tr} 1$ & 1816 & 0.13 & 0.82 & $1.11 \pm 0.04$ & $0.726 \pm 0.019$ & $1.30 \pm 0.05$ & $>350,000$ \\
$\operatorname{Tr} 3$ & 2016 & 0.24 & 0.03 & $1.09 \pm 0.03$ & $13.548 \pm 1.134$ & $0.52 \pm 0.02$ & $78,914+4683 /-4496$ \\
$\operatorname{Tr} 4$ & 1616 & 0.27 & 0.21 & $1.04 \pm 0.03$ & $2.288 \pm 0.083$ & $0.55 \pm 0.02$ & $87,107+4654 /-4466$ \\
$\operatorname{Tr} 5$ & 1716 & 0.35 & 0.14 & $1.01 \pm 0.02$ & $4.240 \pm 0.199$ & $0.55 \pm 0.02$ & $87,555+4839 /-4635$ \\
\hline
\end{tabular}

\subsection{Morpho-Stratigraphical Data}

From a morpho-stratigraphical perspective, different landforms and relative deposits characterize individually the three study sectors as shown in Table 2 that also reports the associated codes hereinafter used in the text to indicate them. 
Table 2. Distribution of main landforms and deposits in the three sectors and associated codes.

\begin{tabular}{ccccc}
\hline Code & Description & Sector A & Sector B & Sector C \\
\hline AL & Ancient alluvial deposits & $X$ & $X$ & $X$ \\
HFT & Ancient fluvial terraces & $X$ & $X$ & \\
AF & Alluvial fans & $X$ & $X$ & $X$ \\
ATD & Amorosi travertine deposits & & $X$ & \\
CI-T & Campanian Ignimbrite pyroclastic flow terrace & & $X$ & $X$ \\
T-T & Telese travertine terrace & $X$ & $X$ & \\
VFT & Valley floor terraces & $X$ & $X$ \\
\hline
\end{tabular}

For each sector, the illustration of overall acquired data is supported by a geomorphological sketch focused on fluvial landforms, a related schematic geological cross profile and borehole logs considered in this study.

\subsubsection{Sector A}

Sector A (Figure 2) is characterized by the presence of ancient alluvial (AL) deposits and related ancient fluvial terraces (HFT) on the right Calore valley flank, and by three orders of valley floor terraces (VFT) and alluvial fans (AF), mainly developed along the left flank.

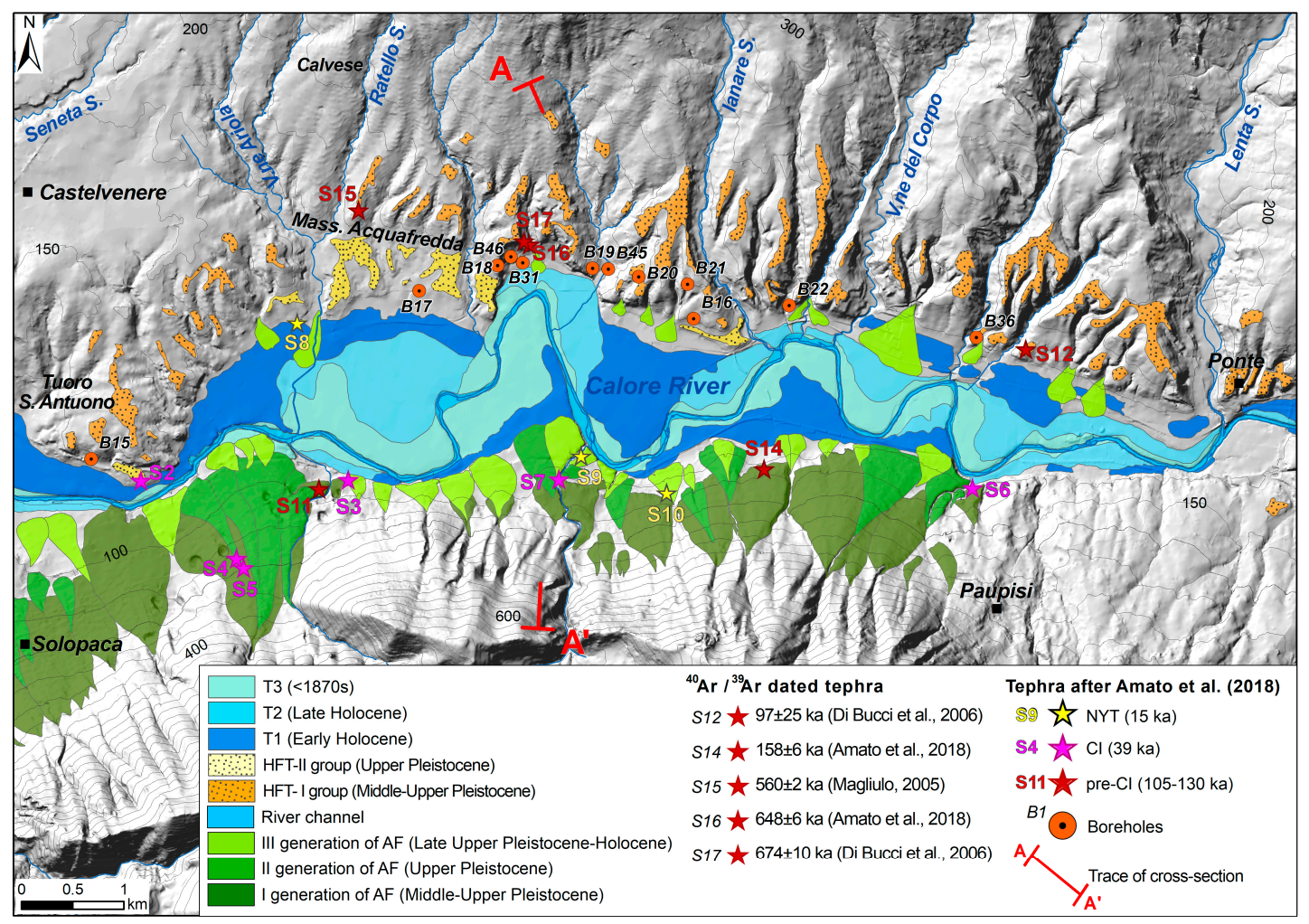

Figure 2. Geomorphological sketch of sector A.

Remnants of HFT are located between 80/90 m and $220 \mathrm{~m}$ a.s.l. (Figure 2). Most of them are both depositional and erosional landforms, formed by or cut in the AL deposits. Some of the highest HFT remnants are cut into bedrock and thinly veneered by a few meters of polygenic fluvial gravels. Frequently, the HFT are reduced to narrow ridges, separated by up to $80 \mathrm{~m}$ deep valleys incised by the tributaries of Calore River. These HFT are quite difficult to correlate, given their poor state of preservation and their high fragmentation, which is due-in agreement with other authors (see Section 2.1)—also to tectonics. Therefore, a careful revision of HFT orders was carried out in this study. Thus, in the geomorphological sketch (Figure 2), we have distinguished two groups of HFT. The first 
group (HFT-I group) includes terrace remnants located between 100 and $220 \mathrm{~m}$ a.s.l. (at 60 to $140 \mathrm{~m}$ above the present channel; a.p.c. hereinafter). The second group (HFT-II group) is made of gently inclined terrace remnants located at $80 / 90 \mathrm{~m}$ a.s.l. (at 10 to $35 \mathrm{~m}$ a.p.c.).

The HTF-I group includes many of the I and II order and some of the III order terrace remnants of Massa et al. [31] and Di Bucci et al. [32,33]. It also includes the I, II, and III order terraces located between Ponte and Masseria Acquafredda, and the I and II order terraces between Masseria Acquafredda and Tuoro S. Antuono of Magliulo et al. [34].

The ancient alluvial (AL) deposits crop out from 65 to $220 \mathrm{~m}$ a.s.l. They mainly consist of moderately well sorted gravels in silty-sandy matrix covering the Meso-Cenozoic bedrock. Their maximum thickness in outcrop is $\sim 80 \mathrm{~m}$ but exceeds even $100 \mathrm{~m}$ in borehole (see B36 in Figure 3). These could be distinguished in two different depositional cycles, named alluvial unit $1 \mathrm{a}$ and alluvial unit $1 \mathrm{~b}$ (Figures 3 and 4 ) and associated respectively to the HFT-I and HFT-II group.

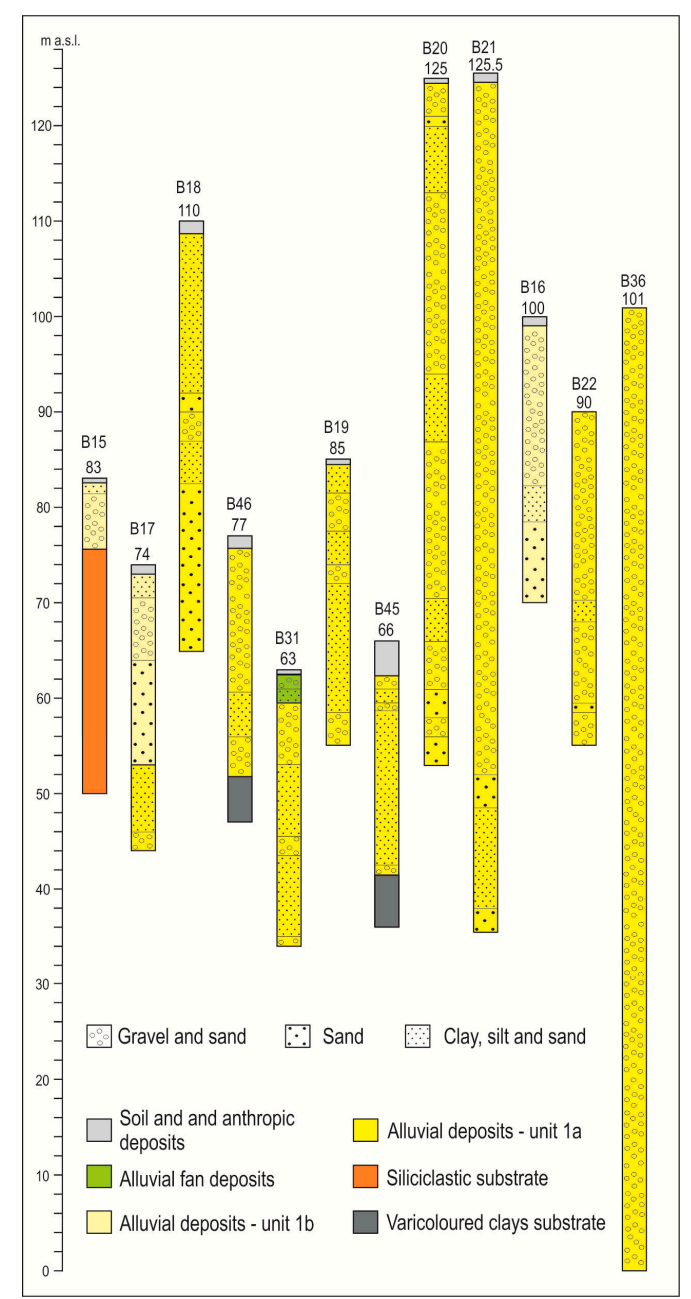

Figure 3. Stratigraphical logs of boreholes drilled through the AL deposits. For location, see Figure 2. 


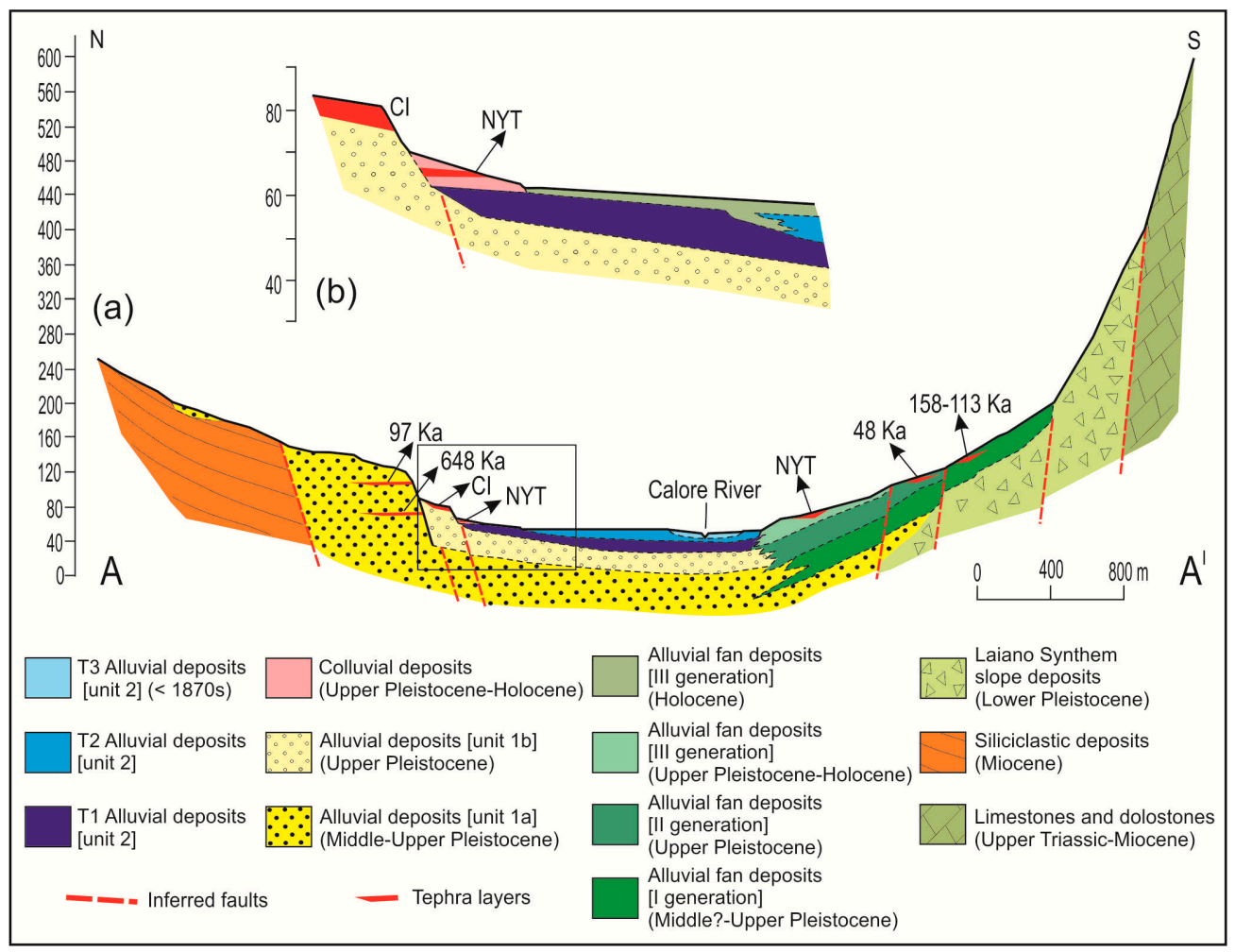

Figure 4. (a) Schematic geological cross section through the Calore River valley in sector A. See Figure 2 for location; (b) detail of the geological cross section showing the relationships between the colluvial deposits containing reworked Neapolitan Yellow Tuff (NYT) deposits, the T1 and T2 alluvial deposits and the deposits of the third generation of AF along the right valley side.

Alluvial unit 1a mainly consists of polygenic, heterometric, predominantly wellrounded pebbles, poorly cemented, with scarce to abundant silty-sandy and/or silty-clayey yellowish matrix, and lenses and layers of coarse to medium sands (few decimeters to some meters thick) (Figure 5a,b). Horizontal bedding imbrications are locally present in gravels levels and reddish erosion surfaces often mark the contact between sandy levels and gravels. In addition, the borehole successions highlight the presence of finegrained intervals, containing beds of blackish organic substance and/or peaty layers. The overall textural characteristics of these deposits suggest a braided stream environment.

Locally, paleosols and tephra layers are intercalated in unit 1a. In particular, at Masseria Acquafredda (S16 in Figure 2; Figure 5c) a $30 \mathrm{~cm}$-thick yellow-brownish $648 \pm 6 \mathrm{ka}$ ${ }^{40} \mathrm{Ar} /{ }^{39} \mathrm{Ar}$ aged tephra layer [15], most likely corresponding to the pyroclastic layer dated to $674 \pm 10$ ka by Di Bucci et al. [33] (S17 in Figure 2), is interbedded in these deposits (Figure 4a). Furthermore, unit 1a contains the $560 \pm 2$ ka aged ignimbrite deposit of Magliulo [30] and the $97 \pm 25 \mathrm{ka}$ aged tephra layer of Di Bucci et al. [33] (Figures 2 and 4a). Therefore, a Middle-Upper Pleistocene age between $\sim 650 \mathrm{ka}$ and $\sim 97 \mathrm{ka}$ can be assumed for this unit and the HFT-I group. This age is also supported by the presence of the CI $(\sim 39 \mathrm{ka})$ pyroclastic flow deposits (Figures $4 \mathrm{a}$ and $5 \mathrm{~d}$ ) filling the V.ne Ariola stream valley, which deeply cuts the HFT-I group, confirming that its formation took place long before the $\mathrm{CI}$ deposition.

Ancient alluvial fan bodies, made of massive, coarse, and medium, poorly rounded polygenic gravels in sandy-silty matrix (Figure 5e), close the fluvial successions that form the highest remnants of the HFT-I group, evidencing that the formation of the latter was influenced also by right tributary inputs of Calore River. 

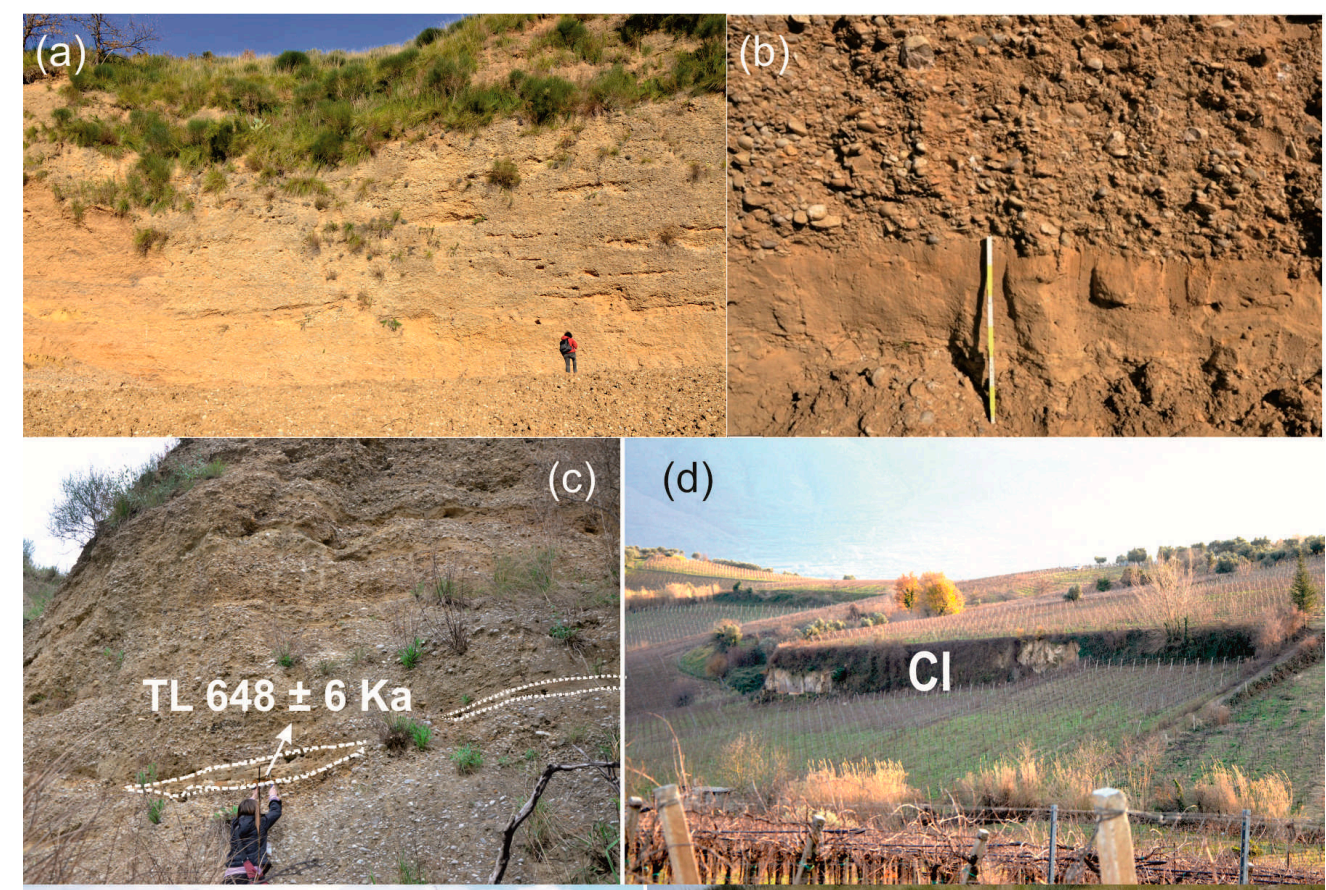

(d)
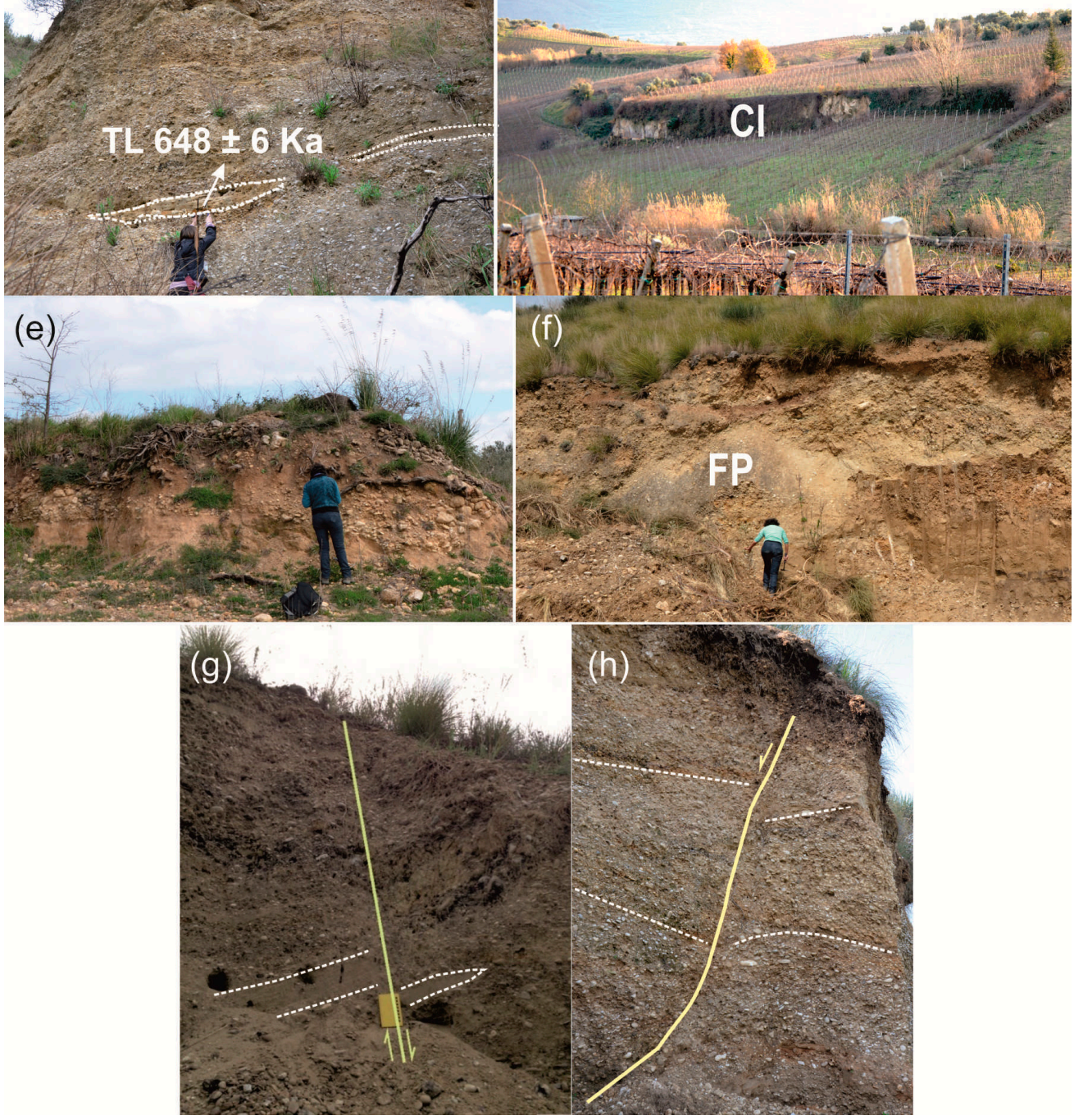

Figure 5. (a) Typical outcrop of alluvial unit 1a and (b) detail of a sandy-silty layer in the lower part. The length of the scale is $60 \mathrm{~cm}$; (c) the $648 \pm 6 \mathrm{ka}{ }^{40} \mathrm{Ar} /{ }^{39} \mathrm{Ar}$ dated Tephra layer (TL) interbedded in the alluvial unit 1a at Masseria Acquafredda.; (d) the Campanian Ignimbrite (CI) pyroclastic flow deposits cropping out in the V.ne Ariola stream valley; (e) massive coarse and medium, poorly rounded polygenic gravels in sandy-silty matrix, cropping out at the top of the oldest HFT remnants; (f) fault plane (FP) in the alluvial unit 1a; (g) decimetric offset in a sandy layer of alluvial unit 1a highlighting a NE-SW oriented fault; (h) dragged pebbles that highlight a NW-SE oriented fault.

Our field surveys have evidenced, in agreement with other authors [15,32-34], that highangle faults have displaced the alluvial unit $1 \mathrm{a}$ and HFT-I group (Figure $5 \mathrm{f}-\mathrm{h}$ ). These faults also controlled the development of the rectilinear, about $25 \mathrm{~m}$ high fluvial scarps that 
terraced the HFT-I group. At the foot of these scarps, the HFT-II group and related alluvial unit $1 b$ are found (Figure $4 a$ ).

The HFT-II group includes some of the terraces attributed to the III order by Massa et al. [31], Di Bucci et al. [32,33] and Magliulo et al. [34].

Collected stratigraphical data highlight that the alluvial unit $1 \mathrm{~b}$, associated with the HFT-II group, reaches at least $30 \mathrm{~m}$ in thickness, and is characterized by coarser deposits, mainly gravelly-sandy, with predominantly carbonate pebbles, which unconformably overlie both unit 1a and the Miocene siliciclastic deposits. The overall textural characteristics of unit $1 \mathrm{~b}$ indicate braided stream environments.

In Tuoro S. Antuono locality, unit $1 \mathrm{~b}$ is covered by CI deposits [15] (S2 in Figure 2) that crop out at the top of a terrace referred to the HFT-II group (Figure 4b). Therefore, in accordance with Di Bucci et al. [32,33], unit $1 \mathrm{~b}$ and the HFT-II group can be constrained to the Upper Pleistocene, between $\sim 97 \mathrm{ka}$ and $39 \mathrm{ka}$ (Figure $4 \mathrm{a}$ ). The HFT-II group terraces are limited towards the Calore valley floor by degraded rectilinear scarps that are controlled by mainly NW-SE trending faults ([15] and reference therein), highlighting that tectonics acted even after the $\mathrm{CI}$ deposition.

Three orders of valley floor terraces (VFT, Table 2; T1, T2, and T3, Figure 2) have been recognized in all sectors (Figure 6). Based on previous and new morpho-stratigraphical data and considerations, we interpret these VFT, in agreement with other authors [31-33,35], as cut and fill terraces. However, collected borehole and field data did not always allow us to clearly distinguish the alluvial fill associated with each order of VFT; therefore we referred all alluvial deposits underlying the single terraces (T1-T3 alluvial deposits, Figure 4) to a generic alluvial unit 2 that can be clearly distinguished from the ancient alluvial deposits (alluvial unit 1, Figure 7).

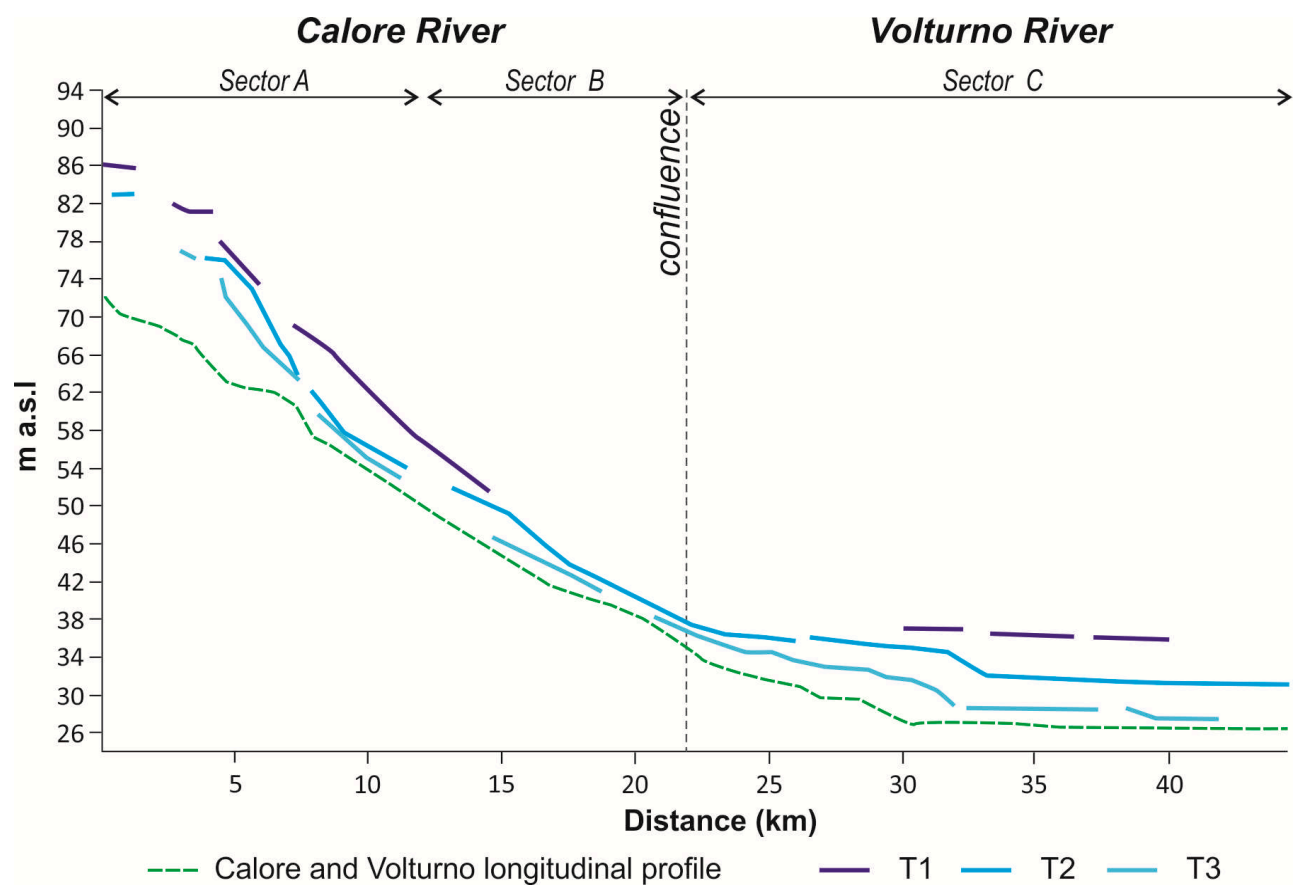

Figure 6. Calore and Volturno rivers longitudinal profiles and reconstruction of valley floor terraces T1-T3. 


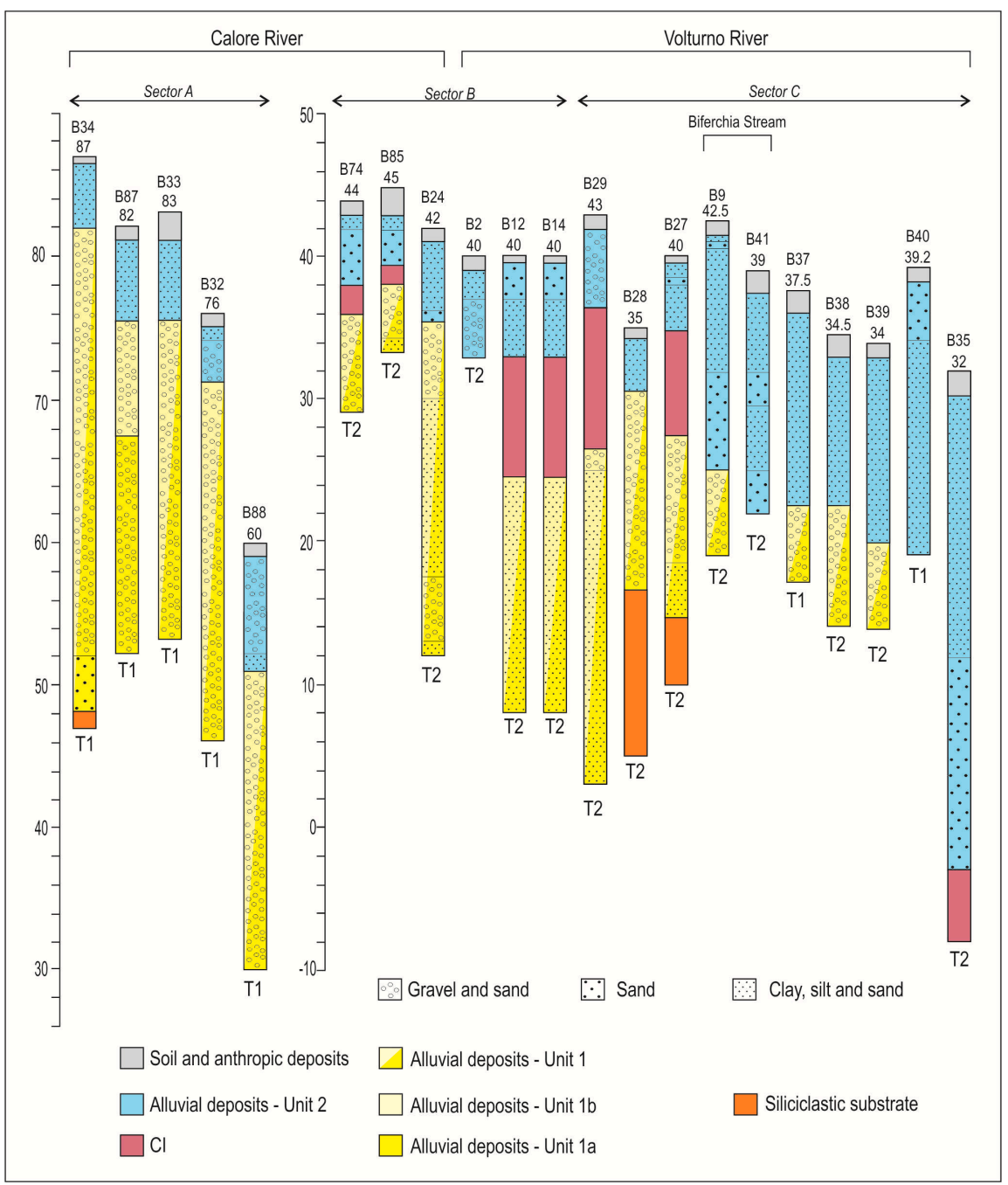

Figure 7. Stratigraphical logs of boreholes drilled through the T1 and T2 VFT (For location seethe geomorphological sketches).

In sector A, these terraces are steeper and convergent along the first $7.5 \mathrm{~km}$ of the longitudinal profile of the Calore River (Figure 6), then show gentler gradients and remain approximately parallel. Average slopes slightly decrease from T1 to T3 (Table 3).

Table 3. Elevation above sea level (a.s.l.), above the modern channel (a.p.c.) and average slopes of terraces $\mathrm{T} 1, \mathrm{~T} 2$, and $\mathrm{T} 3$ in sectors $\mathrm{A}, \mathrm{B}$, and $\mathrm{C}$.

\begin{tabular}{ccccc}
\hline & & Sector $\mathbf{A}$ & Sector B & Sector C \\
\hline \multirow{2}{*}{ T1 } & elevation a.s.l. & from 87 to $54 \mathrm{~m}$ & $52 \mathrm{~m}$ & $37 / 36 \mathrm{~m}$ \\
& elevation a.p.c. & from $\sim 15$ to $\sim 10 \mathrm{~m}$ & $\sim 10 \mathrm{~m}$ & $\sim 9 \mathrm{~m}$ \\
& average slope & $0.0023 \mathrm{~m} / \mathrm{m}$ & $0.0023 \mathrm{~m} / \mathrm{m}$ & $0.0004 \mathrm{~m} / \mathrm{m}$ \\
\hline \multirow{2}{*}{ T2 } & elevation a.s.l. & from 83 to $52 \mathrm{~m}$ & from 52 to $38 \mathrm{~m}$ & from 36 to $29 \mathrm{~m}$ \\
& elevation a.p.c. & from $\sim 12$ to $\sim 8 \mathrm{~m}$ & $\sim 8 / 7 \mathrm{~m}$ & $\sim 6 / 5 \mathrm{~m}$ \\
& average slope & $0.0022 \mathrm{~m} / \mathrm{m}$ & $0.0022 \mathrm{~m} / \mathrm{m}$ & $0.0004 \mathrm{~m} / \mathrm{m}$ \\
\hline \multirow{2}{*}{ T3 } & elevation a.s.l. & from 77 to $50 \mathrm{~m}$ & from 46 to $38 \mathrm{~m}$ & from 33 to $27 \mathrm{~m}$ \\
& elevation a.p.c. & from $\sim 10$ to $\sim 4 \mathrm{~m}$ & $\sim 4 \mathrm{~m}$ & $\sim 4 / 2 \mathrm{~m}$ \\
& average slope & $0.0021 \mathrm{~m} / \mathrm{m}$ & $0.0021 \mathrm{~m} / \mathrm{m}$ & $0.0004 \mathrm{~m} / \mathrm{m}$ \\
\hline
\end{tabular}

T1 is the terrace with the largest areal extension and is present on both valley sides. T2 is well developed especially on the right valley side and reaches a maximum width of $1000 \mathrm{~m}$. Finally, T3 is rather continuous and present on both sides of the valley. It converges 
downstream towards the Calore River channel. Its average width ranges between about $50 \mathrm{~m}$ in the Ponte area and $700 \mathrm{~m}$ downstream. Topographic historical maps show that this terrace order formed after the 1870s.

Only the uppermost layers $(\sim 30 \mathrm{~cm})$ of the deposits forming these three terraces are directly observable. They consist of loose sandy silts with gravels and include reworked terracotta pebbles in T3. Some more information was obtained for T1 by examining borehole data. The deposits forming T1 (alluvial unit 2 in B87, B33, B32, B88; left to right in Figure 7) are 5 to $9 \mathrm{~m}$ thick and rest above Middle-Upper Pleistocene, up to $\sim 35 \mathrm{~m}$ thick alluvial deposits (unit 1 undifferentiated and unit $1 \mathrm{~b}$ in Figure 7) and consist of both fine and coarse sediments. Fine sediments consist of silts, sandy-silts, silty-sands, and siltyclays with plane-parallel lamination (B87 and B33, left to right in Figure 7), sometimes including polygenic pebbles in the upper part, while coarse deposits essentially consist of loose clast-supported heterometric and predominantly rounded carbonate pebbles (B32 and B88, left to right in Figure 7).

In some places, colluvial deposits cover the inner edge of T1 terrace. In the Masseria Acquafredda area, these deposits contain a reworked NYT tephra layer [15] (S8 in Figure 2; Figure $4 a, b$ and Figure $8 a)$.

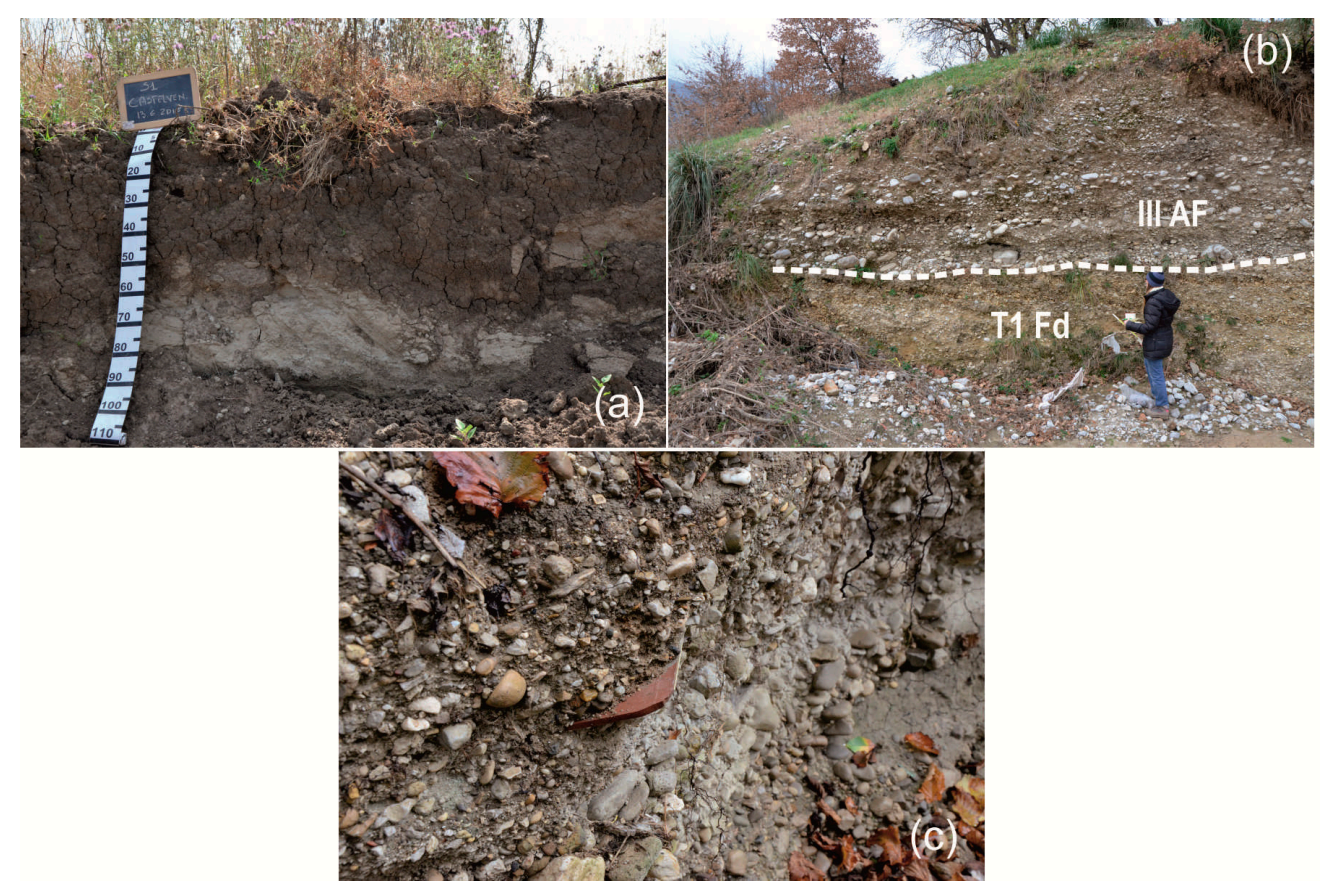

Figure 8. (a) NYT reworked tephra layer in the colluvial deposits covering the T1 terrace; (b) erosional contact (white dotted line) between the deposits of the third AF generation (III AF) and the fluvial deposits of T1 (T1 Fd); (c) heterometric, sub-angular to sub-rounded pebbles of the 3rd AF generation containing recent anthropic artifacts.

While the ancient fluvial terraces (HFT) are dominant along the right Calore valley flank, the left flank is characterized by a high-angle aggradational area, formed by large bodies of the Laiano Synthem slope breccias, which are covered downslope, starting from about $200 \mathrm{~m}$ a.s.l., by alluvial fans (AF, Table 3; Figure 4a). In our geomorphological sketch (Figure 2), we have distinguished three generations of AF.

The first and second generation essentially correspond to the first and second generation of Amato et al. [15], the third one includes the third and fourth generation of these authors. The first generation of AF consists of the largest and steepest alluvial fans found in the study area, sometimes deeply incised and Middle Pleistocene-early Upper Pleistocene in age [15]. In agreement with Amato et al. [15], the gravel deposits of this fan generation either are in lateral heteropy with or overly the upper part of alluvial unit 1a 
(Figure 4a). Like unit 1a, this generation of AF hosts reworked or primary pyroclastic layers (Figures 2 and $4 \mathrm{a}$ ) and paleosols. Furthermore, it seems to have registered the same tectonic phase of the HFT-I group. In fact, it is affected by primarily $\sim \mathrm{E}$ to $\mathrm{W}$ and secondarily NE-SW oriented high-angle faults, which have also controlled the development of largely degraded, rectilinear scarps ( 15 to $30 \mathrm{~m}$ high) terracing in some places the alluvial fans.

The second generation of $\mathrm{AF}$ is entrenched in the first generation and, in some places, incised by channels and affected by E-W and NE-SW high-angle faults, as reported also by [15]. This second generation of AF consists of thinner deposits and is constrained to the late Upper Pleistocene [15] based on the occurrence of the $48 \pm 7 \mathrm{ka}{ }^{40} \mathrm{Ar} /{ }^{39} \mathrm{Ar}$ dated tephra layer (Figure 4a) and the CI layer interbedded in its upper part. Moreover, it rests on the Middle-early Upper Pleistocene alluvial unit 1a, while the three orders of valley floor terraces (VFT) are entrenched within it. Therefore, the growth of this generation of $\mathrm{AF}$ is most likely contemporary up to subsequent (it contains reworked CI tephra deposits) to the formation of the Upper Pleistocene alluvial unit $1 \mathrm{~b}$ and the HFT-II group.

Finally, the third generation of AF includes small and low gradient fans that are often connected downslope to the Calore River alluvial plain. On the left valley side, this generation of AF mostly coincides with the third generation of Amato et al. [15], chronologically constrained to the end of the Upper Pleistocene-Holocene based on the presence of reworked NYT tephra layers in their upper part. These fans are either superimposed or entrenched in the second AF generation and their deposits are either in lateral heteropy with or overlie the deposits of T1 (Figures 4a and 8b), while T2 terraces are mostly entrenched in them (Figure 4a).

The third generation of $\mathrm{AF}$, unlike the other two, is present also on the right Calore valley side (Figure 4a) and corresponds to the fourth generation of Amato et al. [15]. It consists of alluvial fans made of gravelly-sandy deposits with heterometric, sub-angular to sub-rounded pebbles, containing paleosols, archaeological remains and recent anthropic artifacts (Figure 8c). The deposits of this generation of AF cover T1 and T2 terraces and, in some places, interfinger with the T2 deposits (Figure $4 \mathrm{~b}$ ). This generation of AF is chronologically constrained to the Holocene.

\subsubsection{Sector B}

This sector (Figure 9) is dominated by the Telese Plain that occupies a large morphostructural depression (Figure 1b). In the Telese Plain area, the ancient fluvial terraces (HFT) are represented by large surfaces extending between 95 (inner rim) and 75/70 (outer rim) $\mathrm{m}$ a.s.l. (Figures 9 and 10), gently sloping toward and located about $50-30 \mathrm{~m}$ above the Volturno and Calore valley floors. NW-SE and NE-SW oriented rectilinear scarps (about $5 \mathrm{~m}$ high) bound downstream these terraces. Borehole data (B47, B53, B54, and B55 in Figure 11) highlight that their deposits (at least $30 \mathrm{~m}$ thick and referred to alluvial unit 1a), are made of gravelly-sandy successions. Gravel intervals mainly consist of polygenic, heterometric, predominantly well-rounded pebbles with silty-sandy and/or silty-clayey yellowish matrix and levels of coarse to medium sands. The fine-grained, often dominant intervals (up to $13 \mathrm{~m}$ thick), consist of alternations of clayey silts, clays, silty-sandy clays, and sandy silts. 


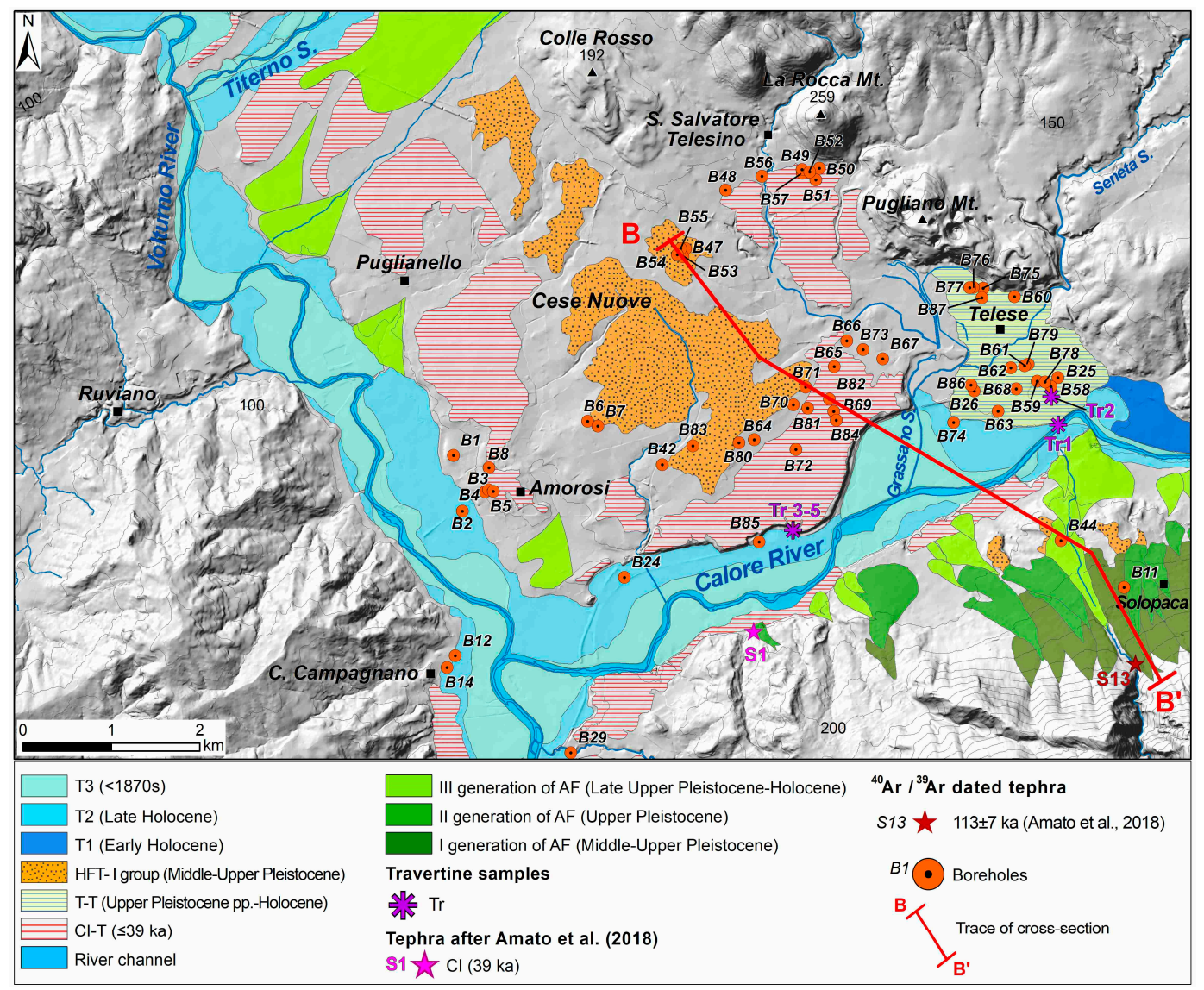

Figure 9. Geomorphological sketch of sector B.

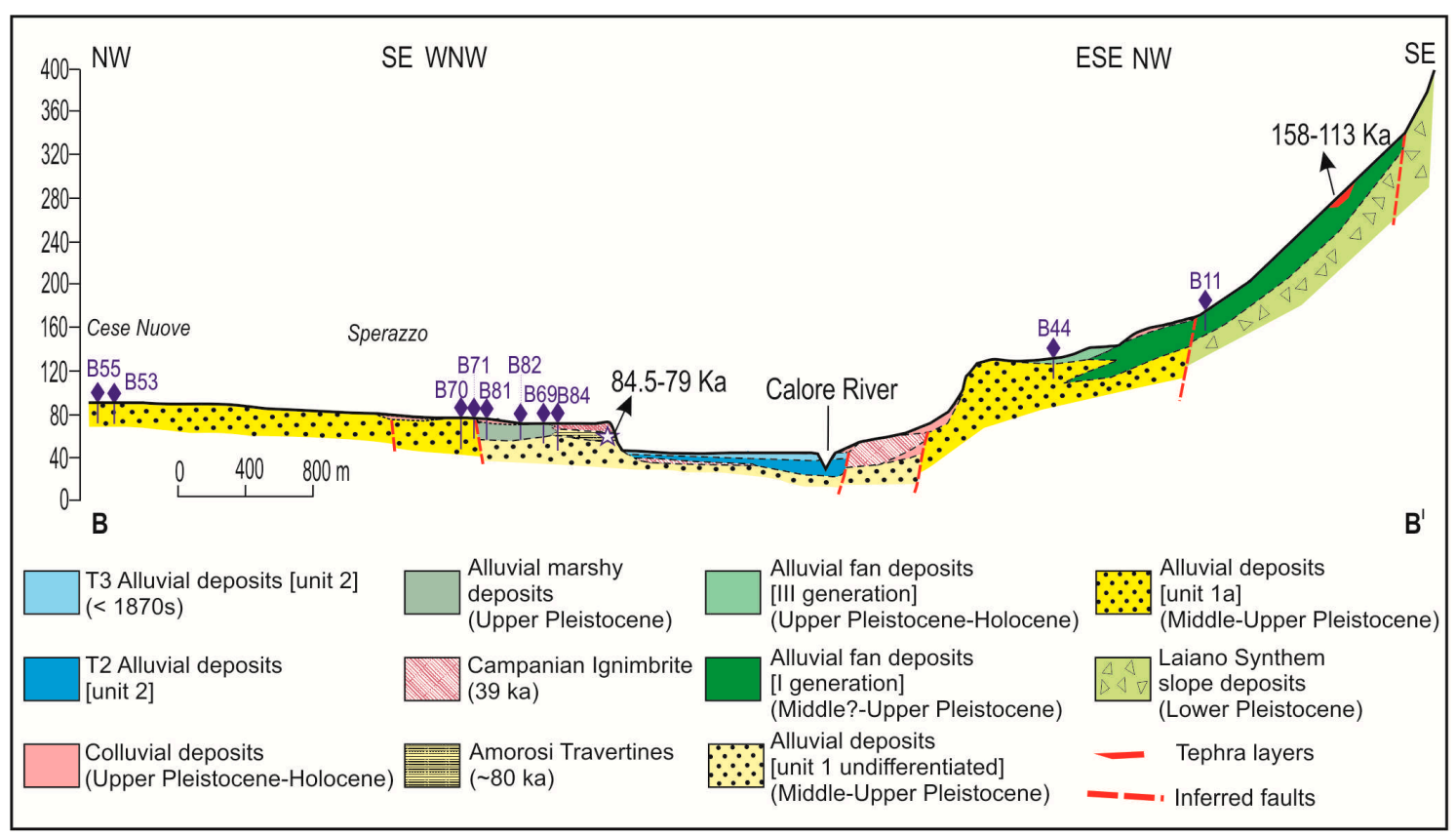

Figure 10. Schematic geological cross section through the Calore River valley in sector B. For location, see Figure 9. 


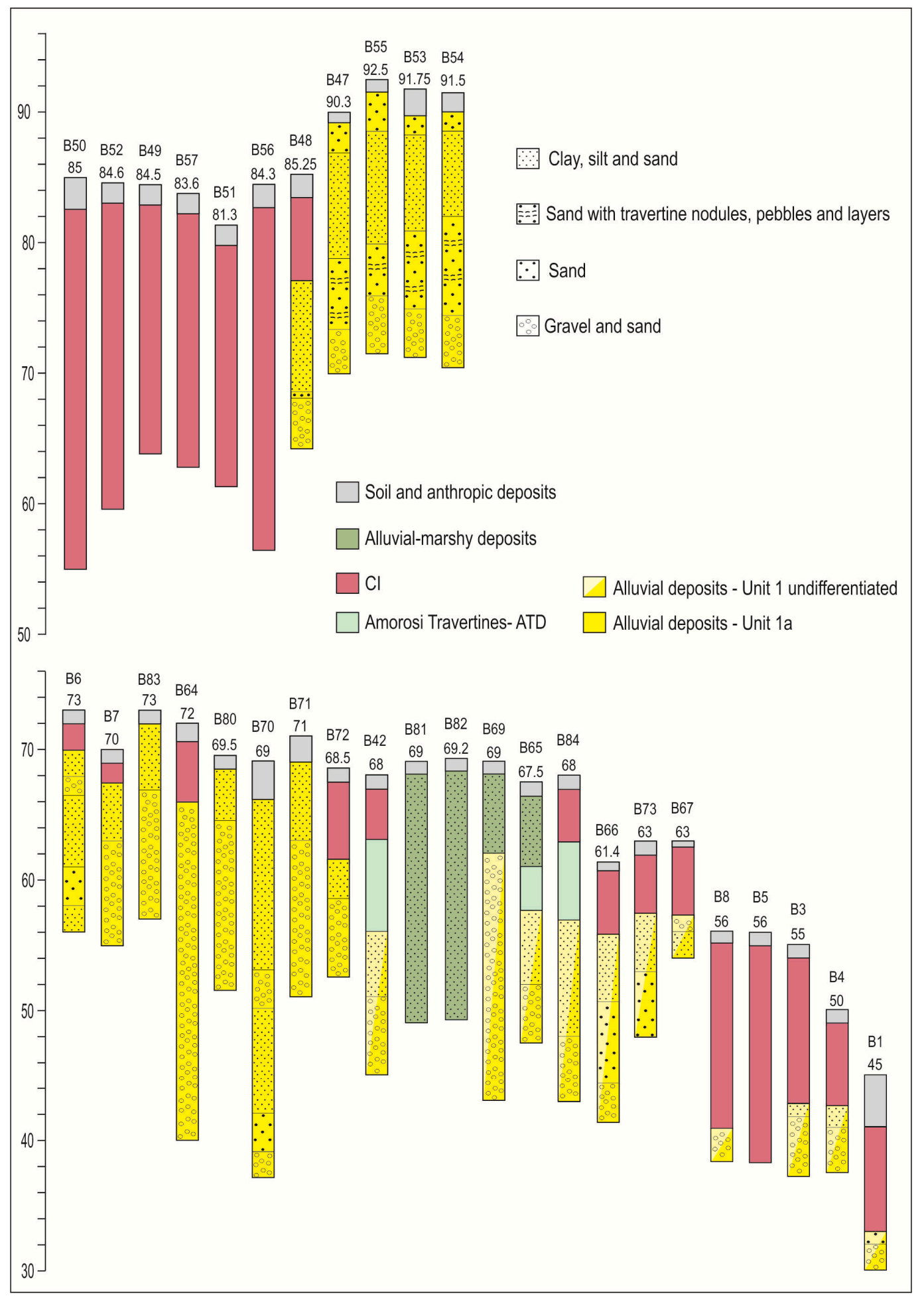

Figure 11. Stratigraphic logs of boreholes drilled in the Telese Plain area on the CI and HFT terraces. For location of boreholes, see Figure 9.

The HFT are incised by deep, partly wide valleys filled with CI pyroclastic flow deposits. This suggests the correlation of these terraces with the Middle-Upper Pleistocene HFT-I group found in sector A, confirming the attribution of their deposits to alluvial unit 1a.

On the left side of the Calore River valley, the HFT are represented by a few small remnants located between 150 and $90 \mathrm{~m}$ a.s.l. at the toe of the Camposauro $\mathrm{Mt}$. in the Solopaca area (Figures 9 and 10). Gravels made of polygenic, well-rounded, heterometric 
pebbles with abundant silty-sandy matrix and local lenses of sands are associated with these surfaces. These deposits either are in lateral heteropy with or covered by the Middle Pleistocene-early Upper Pleistocene deposits of the first generation of alluvial fans (AF, Figure 10, see later), while the late Upper Pleistocene-Holocene second and third generations of AF cover the associated HFT surfaces. Therefore, the chrono-stratigraphical data allow correlating also these terraces with the Middle-early Upper Pleistocene HFTI group, and the related deposits with alluvial unit 1a. Rectilinear scarps, up to $40 \mathrm{~m}$ high and NW-SE and NE-SW oriented, border downstream these HFT and highlight high-angle faults [15] affecting unit 1a. Instead, no fluvial terraces referable to HFT-II group were found.

CI pyroclastic flow deposits form terraces (CI-T, Table 2) which are represented by very large surfaces lying at 65-70 $\mathrm{m}$ a.s.l. both along the right side of the Calore valley and the left side of the Volturno valley, as well as by smaller strips located at $60-65 \mathrm{~m}$ a.s.l. on the left side of the Calore valley (Figure 9).

The maximum thickness of exposed CI deposits is $25 \mathrm{~m}$, while borehole data indicate a thickness of more than $25 \mathrm{~m}$ (B50, B56, upper line, left to right in Figure 11). The CI deposits unconformably overlie alluvial unit 1a (B48, upper line, B6, B7, B64, B72, second line, left to right in Figure 11; Figure 12a) and reach their greatest thicknesses where they filled valleys incised into the HFT-I group, such as the large and deep valley south of San Salvatore Telesino (B50 to B56, Figure 9, upper line in Figure 11).

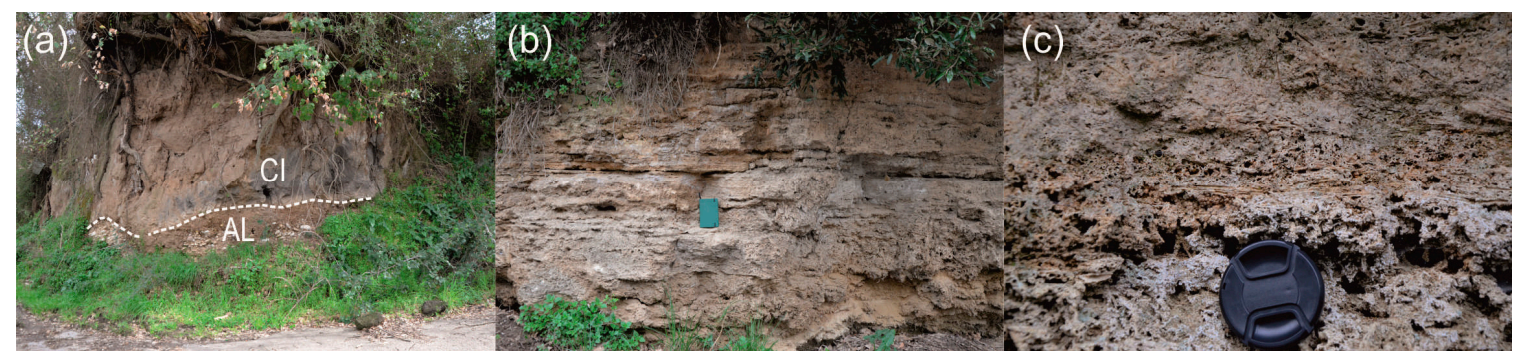

Figure 12. (a) One of the escarpment bordering the CI-T towards the Calore River valley floor, showing the contact between the pyroclastic deposits (CI) and the underlying alluvial unit 1a (AL); (b) the Amorosi travertines; (c) the Telese travertines.

On the left side of the Calore River valley (Camposauro mountain front), CI-T develop at the foot of NE-SW oriented, rectilinear, and partly degraded scarps, and are covered by the second generation of alluvial fans (AF, Figure 9, see below).

The CI deposits that form the Amorosi terrace (70 $\mathrm{m}$ a.sl.) cover the Amorosi travertine deposits (Figures 10 and 12b, ATD in Table 2 and Figure 11). The latter mainly consist of phytohermal travertines and travertine sands reaching a maximum thickness of $5 \mathrm{~m}$ in boreholes and at least $15 \mathrm{~m}$ in outcrop. The ATD overlie alluvial deposits that we referred to the alluvial unit 1 undifferentiated (B42, B65, and B84, bottom line, left to right in Figure 11) since field and borehole data do not allow to establish which of the two depositional cycles (unit 1a or unit $1 \mathrm{~b}$ ) of the ancient alluvial deposits (AL) they represent.

The new ${ }^{230} \mathrm{Th} /{ }^{234} \mathrm{U}$ age of about $80 \mathrm{ka}$ (samples Tr3-Tr5, Table 1 ) allows to chronologically constrain the ATD to the late Upper Pleistocene. Considering their chronostratigraphical position, the deposition of these travertines is most likely contemporaneous to that of the alluvial unit $1 \mathrm{~b}$ found in sector A. Locally, alluvial-marshy deposits (Figure 11) are in lateral heteropy with the ATD and CI deposits.

The Telese travertine terrace (T-T, Table 2, and Figure 9) extends between 65 and $50 \mathrm{~m}$ a.s.l. and marks the depositional surface of the Telese travertines which consist of phytohermal travertines and travertine sands (Figure 12c) reaching a maximum thickness of about $15 \mathrm{~m}$ (Figure 13). These travertines rest on alluvial-marshy deposits that in turn overlie fluvial deposits referable to alluvial unit 1 ; more rarely they directly overlie alluvial unit 1 (B67 and B87, left to right in Figure 13). In the upper part of these travertines, locally alluvial-marshy deposits made of sandy silts containing volcaniclastic material and 
reworked CI clasts (B26, B25, B62, B76, and B75, left to right in Figure 13) are interbedded. They suggest an age younger than $39 \mathrm{ka}$ for the travertines overlying them, confirming, in agreement with Aiello et al. [56] and Del Prete et al. [57], that the T-T is at least in part younger than the ATD. Therefore, considering that in this area the sedimentation of travertines is still active, a late Upper Pleistocene-Holocene age can be assumed for the T-T.

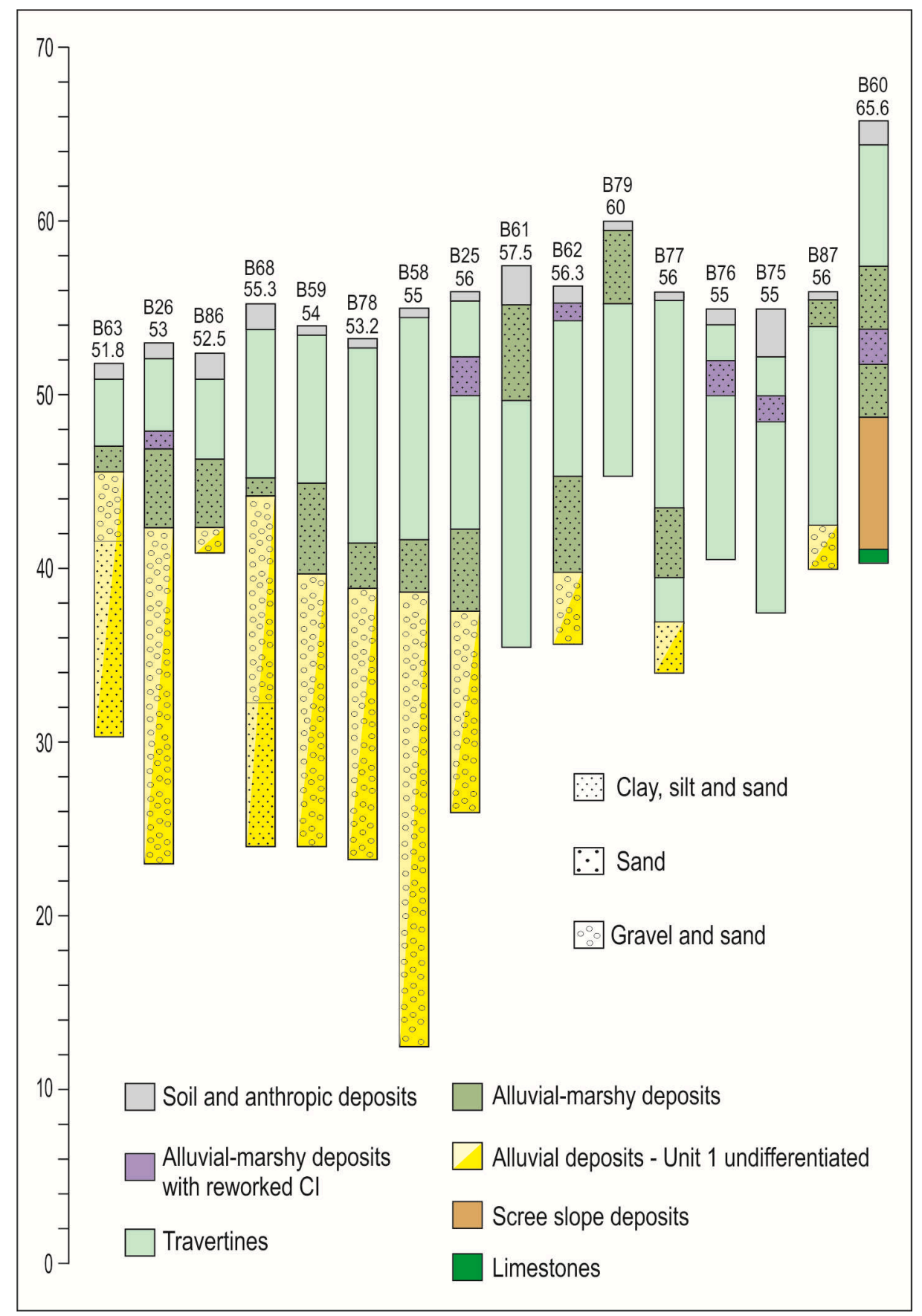

Figure 13. Stratigraphical logs of boreholes drilled on the T-T. For location of boreholes, see Figure 9.

Along the Calore River, the valley floor terraces (VFT) are essentially represented by T2 and T3 (Figures 6 and 9). T1 terrace is only marginally present to the east of Telese, at $52 \mathrm{~m}$ a.s.l. (Table 3), and disappears immediately upstream Telese travertine terrace (T-T). Its altitude, close to that of the lower part of the T-T, suggests that its alluvial deposits are at least partly in lateral heteropy with the Telese travertines. $\mathrm{T} 2$ reaches a maximum 
width of $750 \mathrm{~m}$. T3 terrace is approximately continuous and has an average width of $800 \mathrm{~m}$ immediately downstream of the T-T.

Along the Volturno River, T1 is lacking and T2 and T3 are convergent (Figure 6). $\mathrm{T} 2$ is present between 49 and $36 \mathrm{~m}$ a.s.l. and mostly developed on the right valley side, where it reaches a maximum width of $800 \mathrm{~m}$. T3 is well represented on both valley sides at elevations between 48 and $36 \mathrm{~m}$ a.s.l.

In both river valleys, T2 and T3 terraces are entrenched in the CI terraces (CI-T), located at the foot of vertical scarps, not more than $15 \mathrm{~m}$ high in the Volturno valley and up to $25 \mathrm{~m}$ high in the Calore valley. In addition, in the Calore River valley the T2 terrace is also entrenched in the Telese travertine terrace.

The deposits of T2 (alluvial unit 2 in Figure 7) reach a maximum thickness of $6.5 / 7 \mathrm{~m}$ and mostly consist of medium to coarse sands and sandy-clayey silts predominantly of pyroclastic nature. These deposits rest on CI deposits (with a maximum thickness of $8.5 \mathrm{~m}$ in the Volturno valley) that in turn overlie Middle-Upper Pleistocene alluvial unit 1 (at least $23.5 \mathrm{~m}$ and $16.5 \mathrm{~m}$ thick respectively in the Calore and Volturno valleys).

At the foot of the Amorosi terrace, T2 deposits include, as reported by Calandini et al. [62], a layer containing the Pomici di Avellino deposits $(3.95 \mathrm{ka}[63,64])$ and a silty clay layer rich in ceramic fragments and organic matter. The latter has been radiocarbonically dated to $3500 \pm 60 \mathrm{BP}$ [65], i.e., to $3770 \pm 150 \mathrm{cal} \mathrm{BP}$ (age obtained by using CALIB 8.2 [66] for calibration). These layers, covered by at least two alluvial strata, unconformably overlie an accumulation of CI blocks [62] and highlight that the age of T2 deposits is at least partly referable to the Bronze Age. Finally, a post-1870 age can be attributed to T3 in both river valleys based on editing dates of I.G.M.I. historical topographic maps.

In this sector, all three generations of $\mathrm{AF}$ are present on the left side of Calore valley, while on the left Volturno valley side only the third generation is found. As mentioned above, the upper part of the Middle Pleistocene-early Upper Pleistocene first generation of AF covers the HFT-I group (Figures 9 and 10). The late Upper Pleistocene second generation of AF covers both the HFT-I group and the CI-T, highlighting that its growth started before the emplacement of the CI pyroclastic flow deposits and continued even after. The late Upper Pleistocene-Holocene third generation of AF rests on the HFT-I group and on T2 and T3 terraces and alternatively covers or is entrenched in the CI-T, as can be easily observed along the left Volturno side.

\subsubsection{Sector $\mathrm{C}$}

In this sector, the ancient fluvial terraces (HFT) are lacking and the CI terraces (CI-T) are the highest and oldest surfaces (Figure 14). However, several boreholes located in the valley floor area intercept ancient alluvial deposits $(\mathrm{AL})$. Furthermore, the three orders of valley floor terraces (VFT) are well represented, while only the third generation of alluvial fans $(\mathrm{AF})$ is found.

Borehole data suggest that the Quaternary alluvial infill in this sector of the Volturno valley reaches at least $40 \mathrm{~m}$ in thickness (Figures 7 and 15). In addition, a borehole drilled on the T1 terrace in the Piana di Monte Verna area (borehole number 16952 [67]), crosses even $70 \mathrm{~m}$ of undifferentiated Quaternary sediments before reaching the carbonate bedrock. Part of this infill is represented by pre-CI alluvial deposits (B27 and B29 in Figure 7), which reach a thickness of at least $24 \mathrm{~m}$ and can be referred to the AL alluvial unit 1 undifferentiated. The latter consist of polygenic, heterometric, well-rounded gravels in silty-sandy matrix, containing layers of coarse to medium sands and fine-grained intervals made up of sandy silts, clays, and silty clays, frequently plane-parallel laminated, with beds of blackish organic substance and/or peaty layers. 


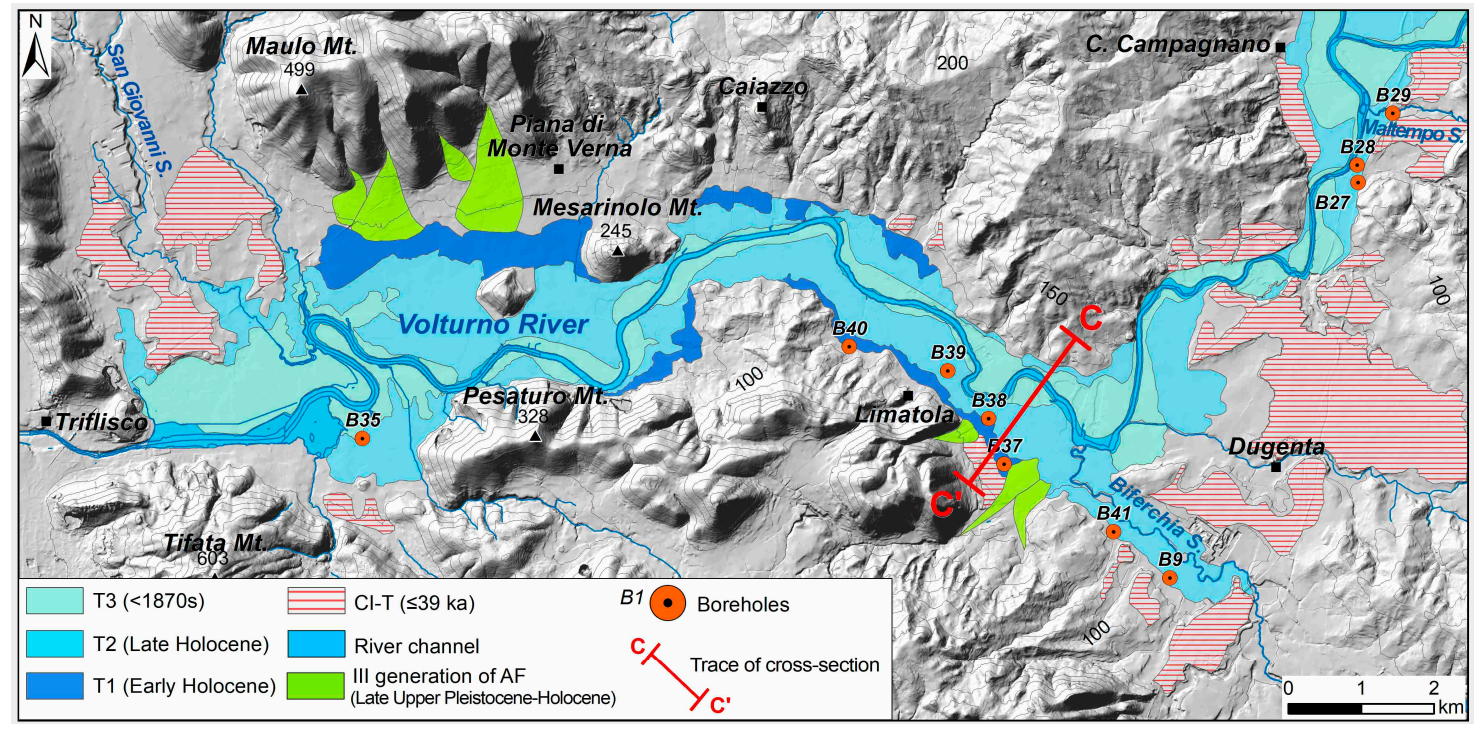

Figure 14. Geomorphological sketch of sector C.

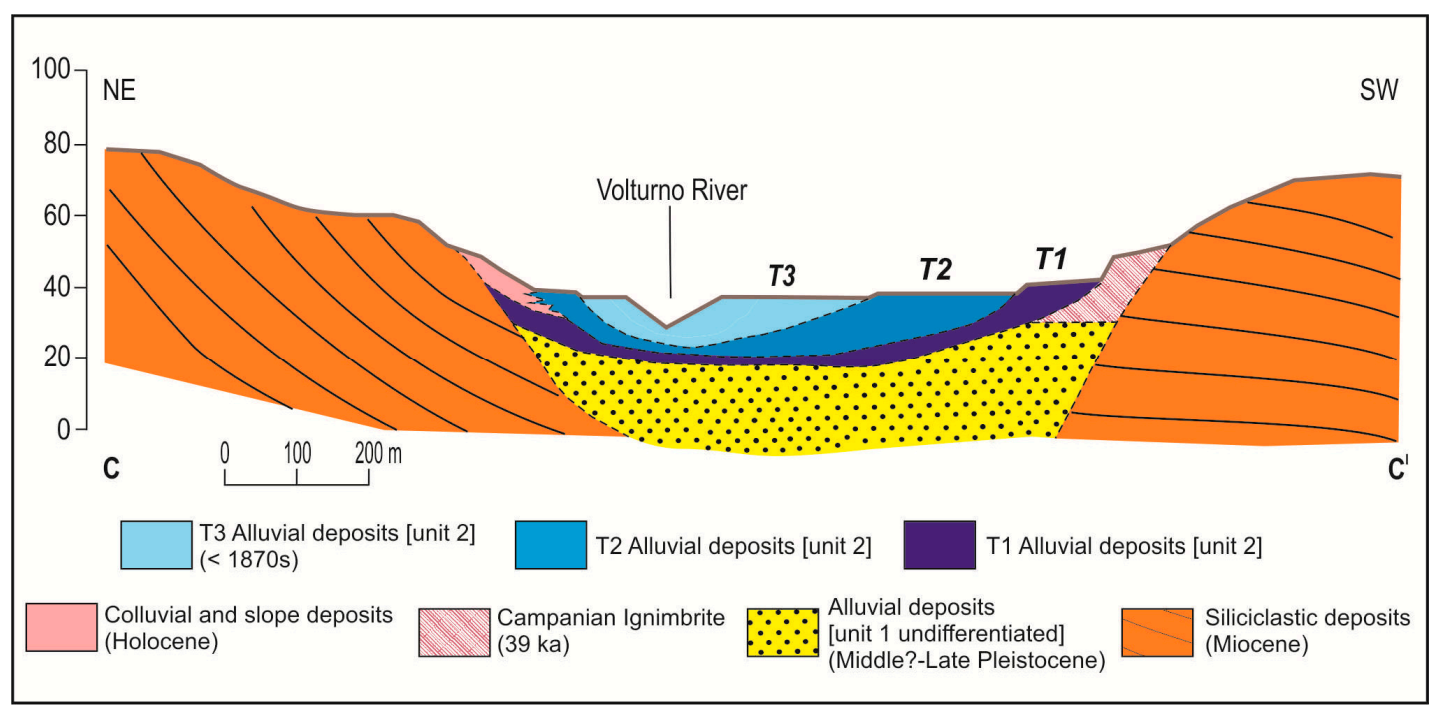

Figure 15. Schematic geological cross section through the Volturno River valley in sector C. For location, see Figure 14.

CI-T are represented by discontinuous, small remnants standing between 44 and $66 \mathrm{~m}$ a.s.l. and 16-18 $\mathrm{m}$ a.p.c. (Figure 14). These terraces are often limited towards the valley floor by up to $15 \mathrm{~m}$ high fluvial scarps.

CI deposits forming these surfaces have maximum thicknesses of about $20 / 25 \mathrm{~m}$ in outcrop and rest on fluvial deposits referable to the alluvial unit 1 undifferentiated (Figures 7 and 15).

All three VFT orders are entrenched in the CI-T (Figure 15). T1 is present exclusively between Limatola and Piana di Monte Verna (Figure 14), at an altitude of 37-36 m a.s.1. (Table 3; Figure 6). It is represented by small terrace remnants, often of limited width, except for those in the Piana di Monte Verna area that reach a width of $800 \mathrm{~m}$. T2 (Figures 6 and 14) is the most continuous and widest terrace (up to $1700 \mathrm{~m}$ wide in Piana di Monte Verna area) and ranges in elevation between 36 and $29 \mathrm{~m}$ a.s.l. T3 (Figures 6 and 16a) is also continuous and its elevation ranges between 33 and $27 \mathrm{~m}$ a.s.l. 


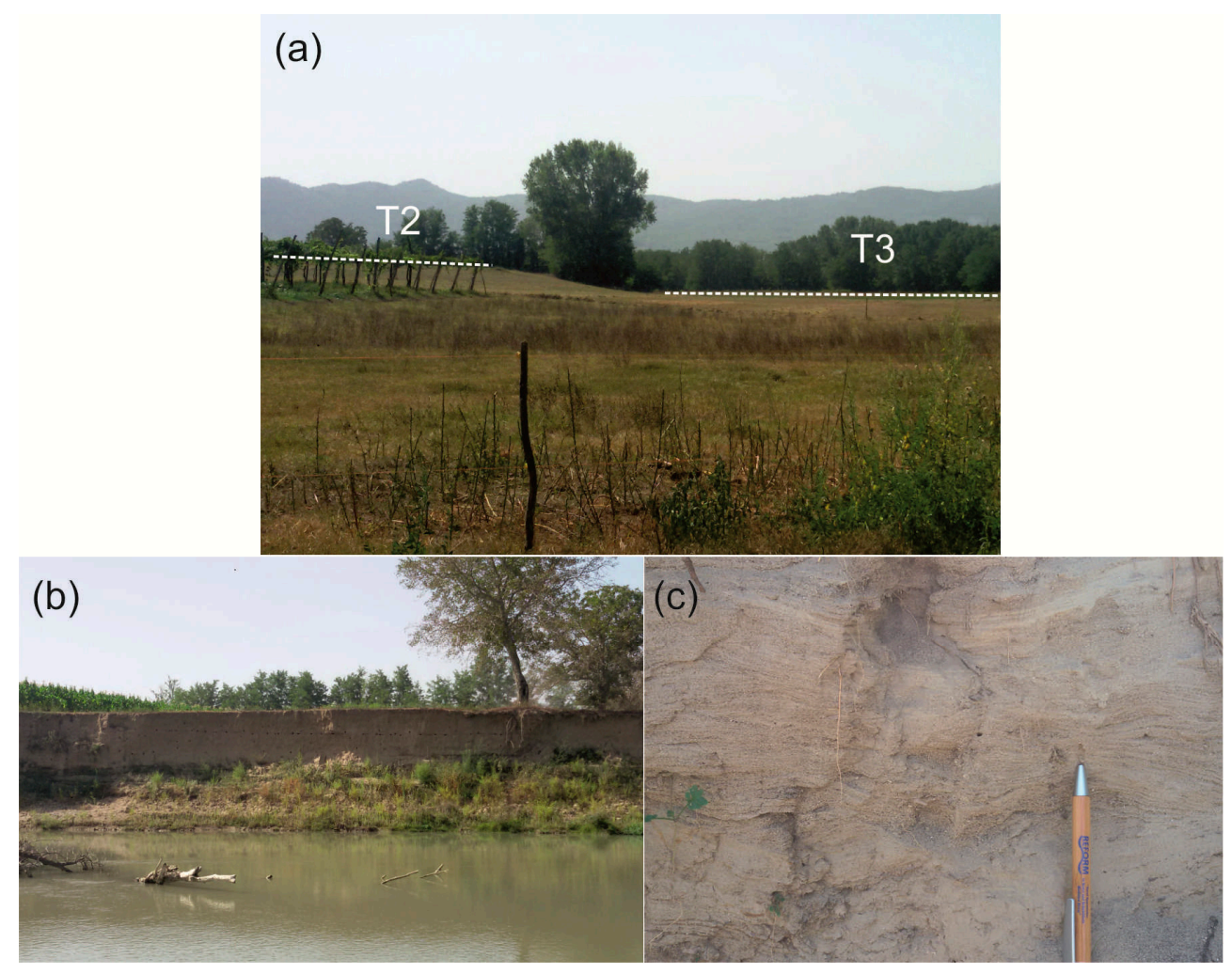

Figure 16. (a) View of T2 and T3 terraces in the Volturno River valley; (b) T3 deposits exposed along the Volturno fluvial scarp; (c) detail of thinly laminated sandy-silty T3 deposits.

$\mathrm{T} 1$ alluvial deposits are mainly of pyroclastic nature and made of fine to coarse sands, thinly layered sandy clayey silts, silty clays, and silty sands. Borehole logs evidence that these deposits (alluvial unit 2 in Figure 7) reach a thickness of about $20 \mathrm{~m}$ and rest on alluvial unit 1 (Figure 15).

Boreholes drilled on the T2 terrace (Figure 7) evidence for alluvial unit 2 a thickness between 4.5 and $17.5 \mathrm{~m}$, except for the area next to the Triflisco dam where it reaches even $35 \mathrm{~m}$. Alluvial unit 2 rests on CI deposits near the Calore confluence (B29 and B27 in Figure 7), downstream the CI-T and in correspondence of the inner edge of the T2 terrace. CI deposits are 7.3 to $10 \mathrm{~m}$ thick and cover alluvial unit 1 . Borehole logs show that alluvial unit 2 is made of fine-grained sediments with a strong volcaniclastic component, mainly consisting of clayey silts, sandy silts, sandy clays, and silty clays, but also of fine to coarse sands. Only in borehole B29 (Figures 7 and 14), probably because of its location near the Maltempo Stream confluence, unit 2 consists of clast-supported, sub-rounded carbonate heterometric gravels with pebbles even exceeding a size of $10 \mathrm{~cm}$.

Medium-fine sands and greyish clay-silts containing a reworked block of NYT, present in the uppermost part of the B27 borehole sequence, confirm that the age of $\mathrm{T} 2$ is certainly younger than $15 \mathrm{ka}$. This is also confirmed by the fact that along the Biferchia Stream the T2 terrace is entrenched in alluvial deposits that can be chronologically constrained between the deposition of CI and NYT [45]. Furthermore, the presence of fragments of pottery and building material referred to Roman farms dated between the II century BCE and II century CE, found on T2 remnants located south of Caiazzo and Piana di Monte Verna villages [68], allow establishing that T2 terraces surely formed before the II century BCE.

T3 deposits (Figure 16b,c) are exposed near the Volturno riverbed along up to $4 \mathrm{~m}$ high fluvial scarps and made of sandy silts and fine sands, often thinly laminated, of predominantly pyroclastic origin. 
In some areas, alluvial fans cover both the T1 and T2 terraces. West of Piana di Monte Verna, the upper parts of these fans contain reworked NYT tephra deposits, confirming their attribution to the third AF generation.

\section{Discussion}

According to Amato et al. [15], the formation of the Volturno and Calore paleovalleys started during the Lower Pleistocene and was controlled by high-angle faults. In the Calore river valley (sectors $\mathrm{A}$ and $\mathrm{B}$ ), extensional tectonics favored the progressive deepening and widening of the valley floors, enhancing in time the local relief that favored the deposition of the Laiano Synthem slope breccias.

Overall now available morpho-stratigraphical data and chronological constraints allow proposing a reconstruction of the evolution of the lower Calore and middle Volturno valleys from the Middle Pleistocene onwards. Several morpho-evolutive steps (Stages A-G, Figure 17) have been individuated, providing new clues on the role of Quaternary tectonic phases, climate changes and volcanic activity in the evolution of these valley systems. Below, the reconstructed stages are illustrated.

Stage A. This stage represents the first phase of valley evolution during the Middle Pleistocene. In the Calore River valley (sectors A and B, Figure 17), $650 \mathrm{ka}$ ago a braided stream depositional environment had already started to develop, as highlighted by the oldest radiometric age ( $\sim 650 \mathrm{ka})$ and the textural characteristics of alluvial unit 1a. During the Middle Pleistocene, the Calore valley was in prevailing aggradation. This aggradation phase most likely encompasses several climate cycles of Middle Pleistocene and was favored by the activity of high-angle faults mainly affecting the Camposauro mountain front, as highlighted by the faulted slope breccias of the Laiano Synthem.

Pending the lack of stringent chronological constraints for the age of alluvial unit 1 undifferentiated, we hypothesize that sector $C$ was occupied only by a narrow valley affected by prevailing erosion during this stage (Figure 17).

Stage B. Between $\sim 650 \mathrm{ka}$ and $\sim 97 \mathrm{ka}$ (Figure 17), the formation of the most ancient fluvial terraces (HFT-I group) took place in the Calore River valley and, towards the end of the Middle Pleistocene ( $150 \mathrm{ka}$ ), also the growth of the first alluvial fans (first AF generation) was fully underway. The deposition of the lower part of these alluvial fans most likely started already in an earlier period of the Middle Pleistocene [15]. The $100 \mathrm{ka}$ climatic variations of the Middle Pleistocene certainly contributed to the development of the HFT-I group and the first AF generation. In particular, the penultimate glaciation (MIS 6) may have significantly concurred to the development of the upper part of this alluvial fan generation.

In sector A, the deposition of alluvial unit 1a and the formation of the related HFT-I group occurred in an asymmetrical valley, affected by a progressive southward migration of its axis, in sector B, instead, in a large morpho-structural depression (Telese Plain area). During this time interval, extensional tectonics mainly acted along NW-SE and NE-SW trending high-angle faults that affected both the HFT-I group and the first AF generation. Tectonics also controlled the development of the straight fluvial scarps, tens of meters high that border the HFT-I group and the first AF generation towards the modern valley floor. This tectonic activity is most likely responsible for the fragmentation of the remnants of HFT-I group, as well as for the different altitudes at which its remnants are located in sector $\mathrm{B}$ on opposite sides of the Calore valley.

In sector $\mathrm{C}$, the thick (up to $70 \mathrm{~m}$ ) pre-CI alluvial infill (alluvial unit 1 undifferentiated; Al-unit 1 in Figure 17) highlights that a watercourse crossed the Volturno valley long before $39 \mathrm{ka}$. Based on the data available to date, it is difficult to establish if fluvial sedimentation started in this sector already at the beginning of this stage; probably it started only during the late Middle Pleistocene. Moreover, also Valente et al. [16] highlight the existence of a valley already drained by the Volturno River during this time interval in the sector immediately upstream of the study area. 
Sector A

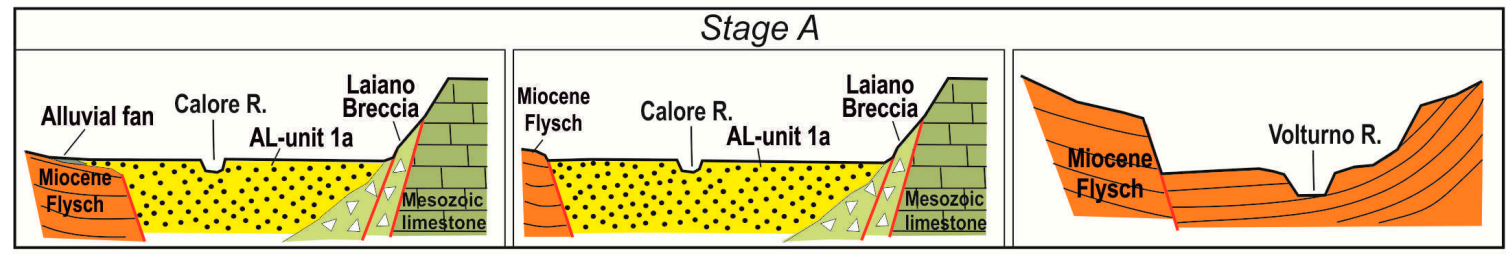
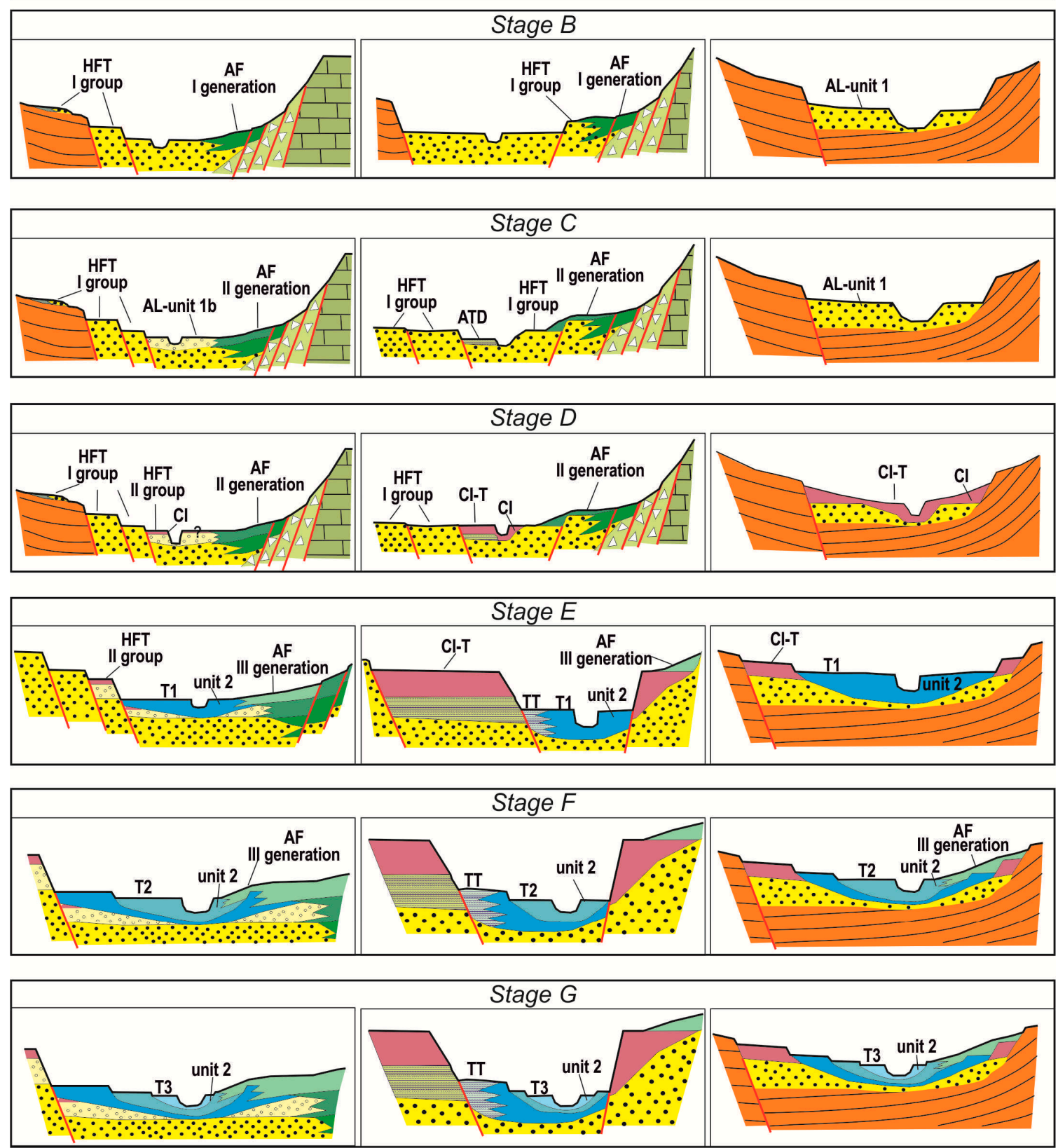

Figure 17. Schematic cross sections (not in scale) illustrating major morpho-evolutive steps (Stages A-G) of the Quaternary landscape evolution reconstructed for the middle Volturno and lower Calore valleys in sectors A, B, and C. The sections refer to the final phase of each stage. From Stage E to Stage G, the cross sections show a zoom of the valley floor areas.

Stage C. Between $\sim 97 \mathrm{ka}$ and $39 \mathrm{ka}$, a new phase of valley floor aggradation occurred in the study area. In sector A, the deposition of alluvial unit $1 \mathrm{~b}$ (Al-unit 1b, Figure 17) took place at the toe of structurally controlled fluvial escarpments bordering the HFT-I group. The textural characteristics of this alluvial unit suggest the persistence of braided stream environments. In sector $\mathrm{B}$, the deposition of the $\sim 80 \mathrm{ka}$ aged Amorosi travertines occurred. 
These travertines are in lateral heteropy with alluvial-marshy deposits that highlight the presence of fluvio-palustrine environments in the Telese area. Along the right Calore side (Camposauro mountain front), the growth of the second generation of $\mathrm{AF}$, covering the alluvial unit 1a and the HFT-I group, started. Finally, in sector C, valley floor aggradation is still recorded by the deposition of Al-unit 1 . This phase of valley floor aggradation probably encompasses several episodes of alluviation that occurred during periods of cold/wet climate and reduced tree cover; in particular, significant river aggradation events in Mediterranean valleys are reported during MIS $5 b$ (or at MIS 5b/5a boundary) and during the first half of MIS $3[14,69]$.

Stage D. At $\sim 39 \mathrm{ka}$, the CI explosive eruption caused the emplacement of large volumes of pyroclastic flow deposits. The latter covered alluvial unit $1 \mathrm{~b}$ (sector $\mathrm{A}$ ) and the Amorosi travertines (sector B), and filled the valleys incised in alluvial unit 1a. The CI pyroclastic flow severely modified the fluvial landscape and completely filled both the Calore (in sector B) and the Volturno valleys (sector C) as well as their tributary valleys. The lack of significant CI deposits in sector A might suggest that the Camposauro Mt. partially sheltered it.

After $39 \mathrm{ka}$, a deep valley incision occurred. The formation of CI terrace (CI-T) occurred most likely immediately after the emplacement of CI deposits and can represent the fluvial response to the valley obstruction caused by the eruption, consisting in the rapid remobilization and erosion of these deposits and consequent restoration of the drainage systems [70-73]. This phase of incision is well recorded in the lower Volturno alluvial plain. Here, a deep (up $30 \mathrm{~m}$ ) incised paleovalley of the Volturno River, following the modern river axis, is cut in CI deposits, and sealed by a first generation of alluvial deposits dated to $37 \mathrm{ka}$ [74]. However, in our hypothesis most of the valley incision occurred only later, during the LGM ( 21 ka [75]), as also recorded in the lower Volturno Plain [74,76-79]. We relate this incision to the upstream propagation of regressive erosion waves from the Tyrrhenian coast, triggered by the base level fall during the LGM low sea level stand. Tectonic subsidence affecting the Campania plain $[76,77,79,80]$ must have further favored the development of retrogressive erosion waves as highlighted by some knickpoints along the longitudinal profile of the Volturno River. Inside the main valleys, instead, the role of intra-chain tectonics is completely marginal and negligible. Due to this phase of valley downcutting, aside from the CI-T formed in sectors B and C, probably most of the HFT-II group formed in sector A. Along the Camposauro mountain front alluvial fan prevailed: the deposition of the second AF generation, which contains reworked CI deposits and covers the CI-T in sector B, continued.

A moderate post-39 ka extensional tectonic phase is highlighted in sectors A and B by NW-SE and by E-W and NE-SW high-angle faults affecting respectively the HFT-II group and the second AF generation. Previous data show that tectonics also affected CI terraces and deposits in the Volturno valley, in sector C and immediately upstream [35,81]. In addition, post-CI fault activity is documented in the Campania Plain [82,83].

Stage E. During this stage, the evolution of the valley floor area and the formation of the valley floor terraces (VFT) started. Furthermore, the deposition of the Telese travertines, which are at least in part in lateral heteropy with the T1 deposits, had already started.

Since no tectonic dislocations are recorded in the three orders of VFT (T1-T3), and in the third alluvial fan generation, climate, and land use changes (natural and man-induced) are supposed to be the main drivers of fluvial dynamics from late Upper Pleistocene onwards.

Regarding the age of $\mathrm{T} 1$ deposits, no clear indications are actually available, and the relationships between them and the Neapolitan Yellow Tuff (NYT) remain unclear: in sector A, T1 terraces are covered by colluvium containing reworked NYT deposits, and the $\mathrm{T} 1$ deposits are either in lateral heteropy or covered by the third generation of AF that also contains reworked NYT tephra. In our hypothesis, the sedimentation of T1 deposits most likely occurred between the Late Glacial and the early Holocene and, therefore, can probably be related to Vita-Finzi's Older Fill [12,84]. Valley aggradation was likely the response to the deglaciation in the Apennines [85] and favored by increased fluvial discharges 
coupled with high availability of sediments, conditions that are well documented for this period $[14,86]$.

A successive phase of valley incision caused the formation of $\mathrm{T} 1$ terrace. This phase of incision may probably be related to the cold-to-warm climate transition $[87,88]$ that occurred between the Younger Dryas/Holocene boundary and the Holocene climate optimum and was characterized by rainfall increase and progressive expansion of temperate forest, well documented in the central-southern Mediterranean area [89,90].

Stage F. The sedimentation of T2 deposits is linked to a phase of valley floor aggradation that occurred from the Mid to Late Holocene (and certainly extended beyond $3.5 \mathrm{ka}$, as suggested by the $3770 \pm 150 \mathrm{cal} \mathrm{BP}$ of organic matter and the Pomici di Avellino level included in their upper part; see Section 4.2.2). This phase of valley aggradation probably encompasses several episodes of alluviation favored by climate deterioration and land cover changes (especially forest reduction). Alluviation was probably favored by cooler conditions such as those recorded in central-southern Italy during the period 7700-5000 cal. BP ([91] and references therein), and by prevailing wetter, partially also cooler conditions (highlighted by higher lake levels and/or a decrease in fire activity) as those reported for the period 7700-6400 cal. BP [92] and from 5000 to 3500 (3000) cal. BP in central Italy [93]. Furthermore, a link between this phase of valley aggradation and periods of increased flooding recorded in the Mediterranean area and southern Italy in particular ([94] and references therein), seems likely. Especially, periods of major flooding occurred in southern Italy at $4200-4100 \mathrm{BP}$ and 3450-3000 cal. BP, which overlap with lake highstands at $4200-4000$ and 3500-3200 cal. BP in central Italy [94], may have played an important role during the terminal part of said phase of alluviation.

On the other hand, the instauration of drier conditions causing vegetation cover and, especially, forest decline may have favored soil erosion and the increase of sediments deliverable to the watercourses also in latter moments. Such periods of climate aridification characterized the central-southern Mediterranean during the Mid Holocene in various moments, and especially around $5.5 \mathrm{ka}$ and at $4.2 \mathrm{ka}[89,90,92,95-98]$. Aside from climate controls, also human activities such as agricultural expansion, cattle breeding, and timber extraction may have contributed to forest decline. In fact, human presence is well documented in the Calore River valley since Neolithic times $[65,99]$, and human impact became significant at least since the late Holocene [65].

Successive fluvial incision led to the formation of $\mathrm{T} 2$ terrace that occurred well after $3.5 \mathrm{ka}$ and before the II century $\mathrm{BCE}$, as highlighted by Roman remains found on the terrace. This phase of incision can possibly be related to the transition towards the "Roman Climatic Optimum" (1 CE-500 CE, [100]).

Stage G. The deposition of T3 deposits may have already started in the late Roman period. It highlights phases of valley floor aggradation due to increased fluvial activity and sediment supply during colder periods, namely the Late Antique Little Ice Age (LALIA, 536-660 CE, [101]) and the Little Ice Age (LIA, 16th-mid 19th century, [102]), corresponding to the so called Vita-Finzi's Younger Fill [12].

The formation of T3 terraces, as already stated, occurred after the 1870s. In the Calore River valley, these terraces largely include the sector of the alluvial plain that, according to Magliulo and Cusano [103], formed during the $<1870-1998$ CE time span.

The late Upper Pleistocene-Holocene third generation of AF grew during the formation of VFT. In accordance with [104], in the Calore River valley many of the alluvial fans referred to this generation, are still active or have been recently reactivated during the destructive flash flood of 15th October 2015. During this flood event, most of the surfaces referred to T2 and T3 terraces in the Calore River valley were flooded [105].

\section{Conclusions}

The present study provides an overall revision of pre-existing and partially contrasting literature data (Section 2.1) on the Quaternary evolution of the Middle Volturno River valley system in a broad sense. This activity allowed getting an order of data, to merge data 
coming from separate or only partially overlapping area, and was the basis for addressing new research activities, to front existing knowledge gaps and improve the overall frame.

New research activities (field surveys, borehole analysis, ${ }^{230} \mathrm{Th} /{ }^{234} \mathrm{U}$ datings on travertines, etc.) added essential stratigraphical, morpho-structural, and geomorphological data, as well as precious chronological constraints. In particular, the ${ }^{230} \mathrm{Th} /{ }^{234} \mathrm{U}$ ages obtained for the Amorosi travertines allowed constraining them to about $80 \mathrm{ka}$ and, along with morpho-stratigraphical data, separating their deposition clearly from that of Telese travertines.

The integrated analyses of pre-existing and new data allowed defining the major stages of the Quaternary evolution of the study area, highlighting:

- Fluvial sedimentation started in the Middle Pleistocene (at least $650 \mathrm{ka}$ ago) within valleys whose formation occurred already during the lower Pleistocene under the control of high-angle faults.

- Extensional tectonics acted during the Middle and Upper Pleistocene, driving the progressive widening and deepening of the valleys, and controlling the formation of the HFT and the first and second generation of AF in both the lower Calore valley and the Calore confluence area (sectors A and B). The HFT and alluvial fans were affected by high-angle faults until the deposition of the $\mathrm{CI}$ in sectors $\mathrm{A}$ and $\mathrm{B}$ occurred, while in the Volturno River valley (sector C), probably due to the extensive deposition of the CI pyroclastic flow deposits, no clear evidence of these faults could be found.

- At $\sim 39 \mathrm{ka}$, the emplacement of large volumes of CI pyroclastic flow deposits severely modified the landscape, completely filling the Volturno valley and the Calore valley in sector B.

- Extensional tectonics acted also after the emplacement of the CI deposits.

- From the end of the Upper Pleistocene onwards $(<15 \mathrm{ka})$, the role of tectonics in the genesis of terraces and alluvial fans appears to be negligible. Climatic and land-use changes played a key role in the formation of the three orders of valley floor terraces and the third generation of alluvial fans.

In conclusion, our study provides an integral comprehensive picture of the Quaternary landscape evolution of the investigated Apennine valley sector and suitable to efficiently address future studies.

New investigations can in particular contribute to improve the data resolution of the valley floor areas, to better clarify the relationships between alluviation/incision cycles and environmental changes (natural or man-induced) during the late Quaternary. For this purpose, the execution of new boreholes on the valley floor terraces, connected paleo-environmental analyses and radiometric datings (extended also to the Telese travertines), can surely contribute to better characterizing the late Quaternary and, especially, Holocene fluvial dynamics and geomorphological evolution of the study area. Data obtainable can increase our knowledge also on the sensibility to environmental changes of the studied river systems in the frame of global climate change.

Author Contributions: Conceptualization, F.F., V.S., and P.P.C.A.; methodology, P.P.C.A., C.M.R., F.F., N.L., V.S., and S.G.; formal analysis, F.F., N.L., V.S., and S.G.; investigation, F.F., N.L., and V.S.; writing—original draft preparation, F.F., P.P.C.A., V.S., N.L., and S.G.; writing-review and editing, C.M.R. and F.F.; supervision C.M.R. and P.P.C.A. All authors have read and agreed to the published version of the manuscript.

Funding: This research was financially supported by University of Naples Parthenope research found grant to P.P.C. Aucelli.

Institutional Review Board Statement: Not applicable.

Informed Consent Statement: Not applicable.

Data Availability Statement: The data presented in this study are available in the article itself and references cited. 
Acknowledgments: The authors wish to thank the Special Issue Editor and the anonymous reviewers whose suggestions contributed to improving the manuscript.

Conflicts of Interest: The authors declare no conflict of interest.

\section{References}

1. Schiattarella, M.; Di Leo, P.; Beneduce, P.; Giano, S.I.; Martino, C. Tectonically driven exhumation of a young orogen: An example from southern Apennines, Italy. In Tectonics, Climate, and Landscape Evolution; Willett, S.D., Hovius, N., Brandon, M.T., Fisher, D., Eds.; Special Paper 398, Penrose Conference Series; The Geological Society of America: Boulder, CO, USA, 2006; Volume 398, pp. 371-385.

2. Amato, V.; Aucelli, P.P.C.; Bracone, V.; Cesarano, M.; Rosskopf, C.M. Long-term landscape evolution of the Molise sector of the central-southern Apennines, Italy. Geol. Carpath. 2017, 68, 24-37. [CrossRef]

3. Miccadei, E.; Piacentini, T.; Buccolini, M. Long-term geomorphological evolution in the Abruzzo area, Central Italy: Twenty years of research. Geol. Carpath. 2017, 68, 19-28. [CrossRef]

4. Vogel, S.; Märker, M.; Rellini, I.; Hoelzmann, P.; Wulf, S.; Robinson, M.; Steinhübel, L.; Di Maio, G.; Imperatore, C.; Kastenmeier, P.; et al. From a stratigraphic sequence to a landscape evolution model: Late Pleistocene and Holocene volcanism, soil formation and land use in the shade of Mount Vesuvius. Quat. Int. 2015, 394, 1-25. [CrossRef]

5. Amorosi, A.; Bracone, V.; Campo, B.; D’Amico, C.; Rossi, V.; Rosskopf, C.M. A late Quaternary multiple paleovalley system from the Adriatic coastal plain (Biferno River, Southern Italy). Geomorphology 2016, 254, 146-159. [CrossRef]

6. Bishop, P. Long-term landscape evolution: Linking tectonics and surface processes. Earth Surf. Process. Landf. 2007, 32, 329-365. [CrossRef]

7. Taylor Perron, J. Climate and the pace of erosional landscape evolution. Annu. Rev. Earth Planet. Sci. 2017, 45, 561-591. [CrossRef]

8. Oguchi, T. Geomorphological debates in Japan related to surface processes, tectonics, climate, research principles, and international geomorphology. Geomorphology 2020, 366, 1-14. [CrossRef]

9. Kumar, A.; Srivastava, P. The role of climate and tectonics in aggradation and incision of Indus River in the Ladakh Himalaya during the late Quaternary. Quat. Res. 2017, 87, 363-385. [CrossRef]

10. Amato, V.; Aucelli, P.P.C.; Bellucci Sessa, E.; Cesarano, M.; Incontri, P.; Pappone, G.; Valente, E.; Vilardo, G. Multidisciplinary approach for fault detection: Integration of PS-InSAR, geomorphological, stratigraphic and structural data in the Venafro intermontane basin (Central-Southern Apennines, Italy). Geomorphology 2017, 283, 80-101. [CrossRef]

11. Blum, M.D.; Törnqvist, T.E. Fluvial responses to climate and sea-level change: A review and look forward. Sedimentology 2000, 47, 2-48. [CrossRef]

12. Vita-Finzi, C. The Mediterranean Valleys: Geological Changes in Historical Times; Cambridge University Press: Cambridge, UK, 1969.

13. Vandenberghe, J. River terraces as a response to climatic forcing: Formation processes, sedimentary characteristics and sites for human occupation. Quat. Int. 2015, 370, 3-11. [CrossRef]

14. Macklin, M.G.; Lewin, J.; Woodward, J.C. The fluvial record of climate change. Phil. Trans. R. Soc. A 2012, 370, 2143-2172. [CrossRef] [PubMed]

15. Amato, V.; Aucelli, P.P.C.; Cesarano, M.; Filocamo, F.; Leone, N.; Petrosino, P.; Rosskopf, C.M.; Valente, E.; Casciello, E.; Giralt, S.; et al. Geomorphic response to late Quaternary tectonics in the axial portion of the Southern Apennines (Italy): A case study from the Calore River valley. Earth Surf. Proc. Landf. 2018, 43, 2463-2480. [CrossRef]

16. Valente, E.; Buscher, J.T.; Jourdan, F.; Petrosino, P.; Reddy, S.M.; Tavani, S.; Corradetti, A.; Ascione, A. Constraining mountain front tectonic activity in extensional setting from geomorphology and Quaternary stratigraphy: A case study from the Matese ridge, southern Apennines. Quat. Sci. Rev. 2019, 219, 47-67. [CrossRef]

17. Delitala, M.C.; Fornaseri, M.; Nicoletti, M. Datazioni Argon-Potassio sulla serie pleistocenica di Isernia la Pineta. In Isernia La Pineta. Un accampamento Più Antico di 700.000 Anni; Coltorti, M., Ed.; Calderini Editore: Bologna, Italy, 1983; pp. 65-66.

18. Van Otterloo, R.H.; Sevink, J. The Quaternary evolution of the Upper Volturno basin. In Isernia La Pineta. Un Accampamento Più Antico di 700.000 Anni; Coltorti, M., Ed.; Calderini Editore: Bologna, Italy, 1983; pp. 35-39.

19. Brancaccio, L.; Cinque, A.; Di Crescenzo, G.; Santangelo, N.; Scarciglia, F. Alcune osservazioni sulla tettonica quaternaria nell'Alta Valle del F. Volturno (Molise). Quaternario 1997, 10, 321-328.

20. Brancaccio, L.; Di Crescenzo, G.; Rosskopf, C.M.; Santangelo, N.; Scarciglia, F. Carta geologica dei depositi quaternari e carta geomorfologica dell'alta valle del fiume Volturno (Molise, Italia meridionale). Note illustrative. Quaternario 2000, 13, 81-94.

21. Coltorti, M.; Ferand, G.; Marzoli, A.; Peretto, C.; Ton That, T.; Voinchet, P.; Bahain, J.J.; Minelli, A.; Thun Hohenstein, U. $\mathrm{New}{ }^{40} \mathrm{Ar} /{ }^{39} \mathrm{Ar}$, stratigraphic and palaeoclimatic data on the Isernia La Pineta Lower Palaeolithic site, Molise, Italy. Quat. Int. 2005, 31, 11-22. [CrossRef]

22. Galli, P.; Giaccio, B.; Messina, P.; Naso, G. L'influenza della tettonica attiva nello sviluppo di terrazzi alluvionali: Il caso della faglia delle AquaeIuliae nella media valle del Volturno (Venafro, appennino centro-meridionale). In Proceedings of the Extended Abstracts of the 27th GNGTS Congress, Trieste, Italy, 6-8 October 2008; pp. 150-154.

23. Galli, P.; Naso, G. Unmasking the 1349 earthquake source (southern Italy): Paleoseismological and archaeoseismological indications from the Aquae Iuliae fault. J. Struct. Geol. 2009, 31, 128-149. [CrossRef]

24. Paris, S.; Sevink, J. Late Wurmian to Early Holocene lake deposits and pyroclastics in the Middle Volturno basin (Caserta Province, Italy). Geol. Romana 1983, 22, 207-210. 
25. Sevink, J.; Paris, S. Late wurmian to early Holocene lake deposits and pyroclastics in the Middle Volturno basin (Caserta Province, Italy). Quaternario 1989, 2, 119-123.

26. Boncio, P.; Dichiarante, A.M.; Auciello, E.; Saroli, M.; Stoppa, F. Normal faulting along the western side of the Matese Mountains: Implications for active tectonics in the Central Apennines (Italy). J. Struct. Geol. 2016, 82, 16-36. [CrossRef]

27. Scorpio, V.; Santangelo, N.; Santo, A. Multiscale map analysis in alluvial fan flood-prone areas. J. Maps 2016, 12, 382-393. [CrossRef]

28. Ascione, A.; Ciotoli, G.; Bigi, S.; Buscher, J.; Mazzoli, S.; Ruggiero, L.; Sciarra, A.; Tartarello, M.C.; Valente, E. Assessing mantle versus crustal sources for non-volcanic degassing along fault zones in the actively extending southern Apennines mountain belt (Italy). Geol. Soc. Am. Bull. 2018, 130, 1697-1722. [CrossRef]

29. Di Nocera, S.; Matano, F.; De Palma, L. Osservazioni geomorfologiche sulla media-bassa valle del fiume Calore (Benevento). Rend. Acc. Sci. Fis. Mat. Napoli 1995, 62, 91-102.

30. Magliulo, P. Quaternarydeposits and geomorphologicalevolution of the Telesina Valley (Southern Apennines). Geogr. Fis. E Din. Quat. 2005, 28, 125-146.

31. Massa, B.; Di Bucci, D.; Tornaghi, M.; Zuppetta, A. Geological survey of the Quaternary deposits in the 1688 Sannio earthquake epicentral area (Benevento, Italy). Boll. Soc. Geol. It. 2005, 4, 105-117.

32. Di Bucci, D.; Massa, B.; Tornaghi, M.; Zuppetta, A. Structural setting of the 1688 Sannio earthquake epicentral area (southern Italy) from surface and subsurface data. J. Geodyn. 2005, 40, 294-315. [CrossRef]

33. Di Bucci, D.; Massa, B.; Zuppetta, A. Relay ramps in active normal fault zones: A clue to the identification of seismogenic sources (1688 Sannio earthquake, Italy). Geol. Soc. Am. Bull. 2006, 118, 430-448. [CrossRef]

34. Magliulo, P.; Russo, F.; Valente, A. Tectonic significance of geomorphological features in the Telesina Valley (Campanian Apennines). Boll. Soc. Geol. It. 2007, 126, 397-409.

35. Massa, B.; Zuppetta, A. Integrated approach to investigation of active tectonic: An example from the Calore river fault system, southern Italy. Ital. J. Geosci. 2009, 128, 505-513. [CrossRef]

36. Barberi, F.; Innocenti, F.; Lirer, L.; Munno, R.; Pescatore, T.; Santacroce, R. The campanian ignimbrite: A major prehistoric eruption in the Neapolitan area (Italy). Bull. Volcanol. 1978, 41, 10-31. [CrossRef]

37. De Vivo, B.; Rolandi, G.; Gans, P.B.; Calvert, A.; Bohrson, W.A.; Spera, F.J.; Belkin, H.E. New constraints on the pyroclastic eruptive history of the Campanian volcanic Plain (Italy). Miner. Petrol. 2001, 73, 47-65. [CrossRef]

38. Sartori, R. The main results of ODP Leg 107 in the frame of Neogene to Recent geology of peri-Tyrrhenian areas. In Proceedings of the Ocean Drilling Program, Scientific Results; Kastens, K.A., Mascle, J., Eds.; Ocean Drilling Program: College Station, TX, USA, 1990; Volume 107, pp. 715-730.

39. Savelli, C.; Schreider, A.A. The opening processes in the deep Tyrrhenian basins of Marsili and Vavilov, as deduced from magnetic and chronological evidence of their igneous crust. Tectonophysics 1991, 190, 119-131. [CrossRef]

40. Patacca, E.; Sartori, R.; Scandone, P. Tyrrhenian basin and Apenninic arcs: Kinematic relations since late Tortonian times. Mem. Soc. Geol. It. 1990, 45, 425-451.

41. Patacca, E.; Scandone, P. Geology of the Southern Apennines. Boll. Soc. Geol. It. Spec. Issue 2007, 7, 75-119.

42. D'Argenio, B.; Pescatore, T.; Scandone, P. Schema geologico dell'Appennino meridionale (Campania e Lucania). In Atti del Convegno Moderne Vedute Sulla Geologia dell'Appennino, Rome, Italy, 16-18 Febbraio 1972; Accademia Nazionale dei Lincei, Problemi Attuali di Scienza e di Cultura, Quaderni: Rome, Italy, 1973; Volume 183, pp. 49-72.

43. Mostardini, F.; Merlini, S. Appennino centro-meridionale. Sezioni Geologiche e Proposta di Modello Strutturale. Mem. Soc. Geol. It. 1986, 35, 177-202.

44. Patacca, E.; Scandone, P.; Bellatalla, L.; Perilli, N.; Santini, U. La zona di giunzione tra l'arco appenninico settentrionale e l'arco appenninico meridionale nell'Abruzzo e nel Molise. In Studi Preliminari All'acquisizione dati del Profilo CROP 11 Civitavecchia-Vasto; Tozzi, M., Cavinato, G.P., Parotto, M., Eds.; Special Issue 1991-2; Studi Geologici Camerti: Camerino, Italy, $1992 ;$ pp. $417-441$.

45. Carannante, G.; Cesarano, M.; Pappone, G.; Putigniano, M.L. Note Illustrative della Carta Geologica d'Italia alla scala 1:50 000 Foglio 431 (Caserta Est); Servizio Geologico d'Italia (ISPRA): Rome, Italy, 2011.

46. Casciello, E.; Cesarano, M.; Pappone, G. Extensional detachment faulting on the Tyrrhenian margin of the Southern Apennines contractional belt (Italy). J. Geol. Soc. 2006, 163, 617-629. [CrossRef]

47. Corrado, S.; Di Bucci, D.; Naso, G.; Butler, R.W.H. Thrusting and strike slip tectonics in the Alto Molise region (Italy): Implications for the Neogene-Quaternary evolution of the Central Apenninic orogenic system. J. Geol. Soc. 1997, 154, 679-688. [CrossRef]

48. Ascione, A.; Cinque, A.; Miccadei, E.; Villani, F.; Berti, C. The Plio- Quaternary uplift of the Apennine chain: New data from the analysis of topography and river valleys in central Italy. Geomorphology 2008, 102, 105-118. [CrossRef]

49. Vezzani, L.; Festa, A.; Ghisetti, F. Geology and tectonic evolution of the central-southern Apennines, Italy. Geol. Soc. Am. Spec. Pap. 2010, 469, 2-58.

50. Pappone, G.; Aucelli, P.P.C.; Cesarano, M.; Putignano, M.L.; Ruberti, D. Note Illustrative della Carta Geologica d'Italia in Scala 1:50 000, Foglio 405 (Campobasso); ServizioGeologicod'Italia (ISPRA): Rome, Italy, 2012.

51. Scorpio, V.; Loy, A.; Di Febbraro, M.; Rizzo, A.; Aucelli, P. Hydromorphology meets mammal ecology: Morphological quality index, recent channel adjustments and otter resilience. River Res. Appl. 2016, 32, 267-279. [CrossRef]

52. Deino, A.L.; Orsi, G.; de Vita, S.; Piochi, M. The age of the Neapolitan Yellow Tuff caldera-forming eruption (CampiFlegrei caldera-Italy) assessed by ${ }^{40} \mathrm{Ar} /{ }^{39} \mathrm{Ar}$ dating method. J. Volcanol. Geotherm. Res. 2004, 133, 157-170. [CrossRef] 
53. Bergomi, C.; Manfredini, M.; Martinelli, G. Note Illustrative dellaCarta Geologica d'Italia alla Scala 1:100 000, Foglio 173 (Benevento); Servizio Geologico d'Italia: Rome, Italy, 1975.

54. Corniello, A.; De Riso, R. Idrogeologia e idrochimica delle sorgenti dell'Agro Telesino. Geol. Appl. Idrogeol. 1986, $21,53-84$.

55. Corniello, A. Lineamenti idrogeochimici delle sorgenti dei principali massicci carbonatici della Campania. Mem. Soc. Geol. It. 1996, 51, 333-342.

56. Aiello, G.; D'Argenio, B.; Ferreri, V.; Violante, C. Ricerche sedimentologiche sui travertini di Telese e di Amorosi (Benevento). In Conferenza Scientifica Annuale sulle Attività di Ricerca dei Dipartimenti, Università di Napoli Federico II; De Frede Ed: Napoli, Italy, 1989; pp. 3-4.

57. Del Prete, S.; Guarino, P.M.; Nisio, S.; Santo, A. I sinkhole in Campania. Mem. Descr. Carta Geolog. Ital. 2008, 85, $149-211$.

58. Bischoff, J.L.; Julià, R.; Mora, R. Uranium-series dating of the Mousterian occupation at Abric Romaní, Spain. Nature 1988, 332, 68-70. [CrossRef]

59. Talvitie, N.A. Electrodeposition of actinides for alpha spectrometric determination. Anal. Chem. 1972, 44, 280-283. [CrossRef]

60. Hallstadius, L. A method for the electrodeposition of actinides. Nucl. Inst. Methods Phys. Res. A 1984, 223, 266-267. [CrossRef]

61. Rosenbauer, R.J. UDATE1: A computer program for the calculation of uranium-series isotopic ages. Comput. Geosci. 1991, 17, 45-75. [CrossRef]

62. Calandini, L.; Di Maio, G.; Fariello, M.; Pizzano, N.; Persiani, C. Montetto (Amorosi): Un insediamento dell'età del Bronzo a controllo dei fiumi Volturno e Calore. In Oebalus, Studi sulla Campania nell'Antichità; Scienze e Lettere: Rome, Italy, 2012; Volume 7, pp. 7-25.

63. Passariello, I.; Albore Livadie, C.; Talamo, P.; Lubritto, C.; D'Onofrio, A.; Terrasi, F. ${ }^{14}$ C chronology of Avellino pumices eruption and timing of human reoccupation of the devastated region. Radiocarbon 2009, 51, 803-816. [CrossRef]

64. Sevink, J.; Van Bergen, M.J.; Van Der Plicht, J.; Feiken, H.; Anastasia, C.; Huizinga, H. Robust date for the Bronze Age Avellino eruption (Somma-Vesuvius): $3945 \pm 10$ calBP (1995 \pm 10 calBC). Quat. Sci. Rev. 2011, 30, 1035-1046. [CrossRef]

65. Bisogno, M.; Fariello, G.; Di Maio, G.; Sperandeo, G. Geoarcheologia e ambiente antico lungo la Media e Bassa Valle del Calore beneventano. In Il Futuro della Memoria, 1, Le Scienze della Terra e l'Archeometria, Napoli, Italy, 20-21 Febbraio 1997; D'Amico, C., Albore Livadie, C., Eds.; Isituto Universitario Suor Orsola Benincasa: Napoli, Italy, 1997; pp. 210-215.

66. Stuiver, M.; Reimer, P.J.; Reimer, R.W. CALIB 8.2 [WWW Program]. Available online: http://calib.org (accessed on 22 December 2020).

67. Dipartimento per il Servizio Geologico d'Italia-ISPRA. Archivio Nazionale delle Indagini nel Sottosuolo (Legge 464/1984). Available online: http:/ /sgi2.isprambiente.it/indagini/scheda_indagine.aspx?Codice=16952 (accessed on 7 January 2021).

68. Quilici Gigli, S.; Quilici, L. Carta Archeologica e Ricerche in Campania/Fascicolo 1, Comuni di Alvignano, Baia e Latina, Caiazzo, Castel Campagnano, Castel di Sasso, Dragoni, Piana di Monte Verna, Ruviano; L'Erma di Bretschneider: Rome, Italy, $2004 ;$ p. 451.

69. Macklin, M.G.; Fuller, I.C.; Lewin, J.; Maas, G.S.; Passmore, D.G.; Rose, J.; Woodward, J.C.; Black, S.; Hamlin, R.H.B.; Rowan, J.S. Correlation of fluvial sequences in the Mediterranean basin over the last $200 \mathrm{ka}$ and their relationship to climate change. Quat. Sci. Rev. 2002, 21, 1633-1641. [CrossRef]

70. Manville, V.; Newton, E.H.; White, J.D.L. Fluvial responses to volcanism: Resedimentation of the 1800a Taupo ignimbrite eruption in the Rangitaiki River catchment, North Island, New Zealand. Geomorphology 2005, 65, 49-70. [CrossRef]

71. Manville, V.; Németh, K.; Kano, K. Source to sink: A review of three decades of progress in the understanding of volcaniclastic processes, deposits, and hazards. Sediment. Geol. 2009, 220, 136-161. [CrossRef]

72. Pierson, T.C.; Major, J.J. Hydrogeomorphic effects of explosive volcanic eruptions on drainage basins. Annu. Rev. Earth Planet. Sci. 2014, 42, 469-507. [CrossRef]

73. Major, J.J.; Bertin, D.; Pierson, T.C.; Amigo, A.; Iroum, A.; Ulloa, H.; Castro, J. Extraordinary sediment delivery and rapid geomorphic response following the 2008-2009 eruption of Chaitén Volcano, Chile. Water Resour. Res. 2016, 52, 5075-5094. [CrossRef]

74. Amorosi, A.; Pacifico, A.; Rossi, V.; Ruberti, D. Late Quaternary incision and deposition in an active volcanic setting: The Volturno valley fill, southern Italy. Sediment. Geol. 2012, 282, 307-320. [CrossRef]

75. Mix, A.C.; Bard, E.; Schneider, R. Environmental processes of the ice age: Land, oceans, glaciers (EPILOG). Quat. Sci. Rev. 2001, 20, 627-657. [CrossRef]

76. Romano, P.; Santo, A.; Voltaggio, M. L'evoluzione geomorfologica della pianura del F. Volturno (Campania) durante il tardo Quaternario (Pleistocene medio-superiore-Olocene). Quaternario 1994, 7, 41-56.

77. Santangelo, N.; Romano, P.; Ascione, A.; Russo Ermolli, E. Quaternary evolution of the Southern Apennines coastal plains: A review. Geol. Carpath. 2017, 68, 43-56. [CrossRef]

78. Matano, F.; Sacchi, M.; Vigliotti, M.; Ruberti, D. Subsidence trends of Volturno River Coastal Plain (Northern Campania, Southern Italy) inferred by SAR Interferometry Data. Geosciences 2018, 8, 8. [CrossRef]

79. Corrado, G.; Amodio, S.; Aucelli, P.P.C.; Pappone, G.; Schiattarella, M. The subsurface geology and landscape evolution of the Volturno coastal plain, Italy: Interplay between tectonics and sea-level changes during the Quaternary. Water 2020, $12,3386$. [CrossRef]

80. Corrado, G.; Amodio, S.; Aucelli, P.P.C.; Incontri, P.; Pappone, G.; Schiattarella, M. Late quaternary geology and morphoevolution of the Volturno coastal plain, southern Italy. Alp. Mediterr. Quat. 2018, 31, $23-26$. 
81. Valente, E.; Ascione, A.; Ciotoli, G.; Porfido, S.; Tavani, S. New data on the late Quaternary tectonics in the epicentral area of the December 2013-January 2014 southern Matese seismic sequence (Southern Apennines). Rend. Online Soc. Geol. It. 2015, 36, 79.

82. Cinque, A.; Ascione, A.; Caiazzo, C. Distribuzione spazio-temporale e caratterizzazione della fogliazione quaternaria in Appennino meridionale. In Le Ricerche del GNDT Nel Campo della Pericolosità Sismica; Galadini, F., Meletti, C., Rebez, A., Eds.; CNR_-Gruppo Nazionale per la Difesa dai Terremoti: Rome, Italy, 2000; pp. 203-218.

83. Valente, E.; Ascione, A.; Santangelo, N.; Santo, A. Late Quaternary geomorphological evolution and evidence of post-Campania Ignimbrite (40 ka) fault activity in the inner sector of the Sarno Plain (Southern Apennines, Italy). Alp. Mediterr. Quat. 2019, 32, 185-197.

84. Leopold, L.B.; Vita-Finzi, C. Valley Changes in the Mediterranean and America and their Effects on Humans. Proc. Am. Phil. Soc. 1998, 142, 1-17.

85. Cordier, S.; Adamson, K.; Dlemas, M.; Calvet, M.; Harmand, D. Of ice and water: Quaternary fluvial response to glacial forcing. Quat. Sci. Rev. 2017, 166, 57-73. [CrossRef]

86. Vandenberghe, J.; Kasse, C.; Bohncke, S.; Kozarski, S. Climate-related river activity at the Weichselian-Holocene transition: A comparative study of the Warta and Maas rivers. Terra Nova 1994, 6, 476-485. [CrossRef]

87. Bridgland, D.; Westaway, R. Climatically controlled river terrace staircases: A worldwide Quaternary phenomenon. Geomorphology 2008, 98, 285-315. [CrossRef]

88. Vandenberghe, J. The fluvial cycle at cold-warm-cold transitions in lowland regions: A refinement of theory. Geomorphology 2008, 98, 275-284. [CrossRef]

89. Combourieu-Nebout, N.; Peyron, O.; Bout-Roumazeilles, V.; Goring, S.; Dormoy, I.; Joannin, S.; Sadori, L.; Siani, G.; Magny, M. Holocene vegetation and climate changes in the central Mediterranean inferred from a high-resolution marine pollen record (Adriatic Sea). Clim. Past. 2013, 9, 2023-2042. [CrossRef]

90. Desprat, S.; Combourieu-Nebout, N.; Essallami, L.; Sicre, M.A.; Dormoy, I.; Peyron, O.; Siani, G.; Bout Roumazeilles, V.; Turon, J.L. Deglacial and Holocene vegetation and climatic changes in the southern Central Mediterranean from a direct land-sea correlation. Clim. Past. 2013, 9, 767-787. [CrossRef]

91. Peyron, O.; Goring, S.; Dormoy, I.; Kotthoff, U.; Pross, J.; de Beaulieu, J.; Drescher-Schneider, R.; Vannière, B.; Magny, M. Holocene seasonality changes in the central Mediterranean region reconstructed from the pollen sequences of Lake Accesa (Italy) and Tenaghi Philippon (Greece). Holocene 2011, 21, 131-146. [CrossRef]

92. Magny, M.; de Beaulieu, J.L.; Drescher-Schneider, R.; Vannière, B.; Walter-Simonnet, A.V.; Miras, Y.; Millet, L.; Bossuet, G.; Peyron, O.; Brugiapaglia, E.; et al. Holocene climate changes in the central Mediterranean as recorded by lake-level fluctuations at Lake Accesa (Tuscany, Italy). Quat. Sci. Rev. 2007, 26, 1736-1758. [CrossRef]

93. Vannière, B.; Power, M.J.; Roberts, N.; Tinner, W.; Carrión, J.; Magny, M.; Bartlein, P.; Colombaroli, D.; Daniau, A.L.; Finsinger, W.; et al. Circum-Mediterranean fire activity and climate changes during the mid-Holocene environmental transition (8500-2500 cal. BP). Holocene 2011, 21, 53-73. [CrossRef]

94. Benito, G.; Macklin, M.G.; Zielhofer, C.; Jones, A.F.; Machado, M.J. Holocene flooding and climate change in the Mediterranean. Catena 2015, 130, 13-33. [CrossRef]

95. Magny, M.; Peyron, O.; Sadori, L.; Ortu, E.; Zanchetta, G.; Vannière, B.; Tinner, W. Contrasting patterns of precipitation seasonality during the Holocene in the south- and north-central Mediterranean. J. Quat. Sci. 2011, 27, 290-296. [CrossRef]

96. Zanchetta, G.; Bar-Matthews, M.; Drysdale, R.N.; Lionello, P.; Ayalon, A.; Hellstrom, J.C.; Isola, I.; Regattieri, E. Coeval dry events in the central and eastern Mediterranean basin at 5.2 and 5.6 ka recorded in Corchia (Italy) and Soreq caves (Israel) speleothems. Glob. Planet. Change 2014, 122, 130-139. [CrossRef]

97. Di Rita, F.; Lirer, F.; Bonomo, S.; Cascella, A.; Ferraro, L.; Florindo, F.; Insinga, D.D.; Lurcock, P.C.; Margaritelli, G.; Petrosino, P.; et al. Late Holocene forest dynamics in the Gulf of Gaeta (central Mediterranean) in relation to NAO variability and human impact. Quat. Sci. Rev. 2018, 179, 137-152. [CrossRef]

98. Bini, M.; Zanchetta, G.; Perşoiu, A.; Cartier, R.; Català, A.; Cacho, I.; Dean, J.R.; Rita, F.D.; Drysdale, R.N.; Finnè, M.; et al. The 4.2 ka BP Event in the Mediterranean region: An overview. Clim. Past. 2019, 15, 555-577. [CrossRef]

99. Langella, M.; Andaloro, E.; Bocci, M.; Boscaino, M.; Coppa, A.; Curci, A.; De Francesco, A.M.; Senatore, M.R.; Rampa, S.; Vargiu, R. Foglianise (Bn), loc. S. Maria a' Peccerella: Un insediamento di tipo Laterza. Riv. Sci. Priest. 2008, 58, 165-190.

100. Margaritelli, G.; Cacho, I.; Català, A.; Barra, M.; Bellucci, L.; Lubritto, C.; Rettori, R.; Lirer, F. Persistent warm Mediterranean surface waters during the Roman period. Sci. Rep. 2020, 10, 10431. [CrossRef] [PubMed]

101. Büntgen, U.; Myglan, V.S.; Ljungqvist, F.C.; McCormick, M.; Di Cosmo, N.; Sig, M.; Jungclaus, J.; Wagner, S.; Krusic, P.J.; Esper, J.; et al. Cooling and societal change during the Late Cooling and societal change during the Late Antique Little Ice Age from 536 to around 660 AD. Nat. Geosci. 2016, 9, 231-236. [CrossRef]

102. Mann, M.E. Little Ice Age. In Encyclopedia of Global Environmental Change, Volume 1., The Earth System: Physical and Chemical Dimensions of Global Environmental Change; MacCracken, M.C., Perry, J.S., Munn, T., Eds.; John Wiley \& Sons Ltd: Chichester, UK, 2002; Volume 1, pp. 504-509.

103. Magliulo, P.; Cusano, A. Geomorphology of the Lower Calore River alluvial plain (Southern Italy). J. Maps 2016, 12, 1119-1127. [CrossRef] 
104. Santo, S.; Santangelo, N.; Forte, G.; De Falco, M. Post flash flood survey: The 14th and 15th October 2015 event in the PaupisiSolopaca area (Southern Italy). J. Maps 2016, 13, 19-25. [CrossRef]

105. Guerriero, L.; Focareta, M.; Fusco, G.; Rabuano, R.; Guadagno, F.M.; Revellino, P. Flood hazard of major river segments, Benevento Province, Southern Italy. J. Maps 2018, 14, 597-606. [CrossRef] 